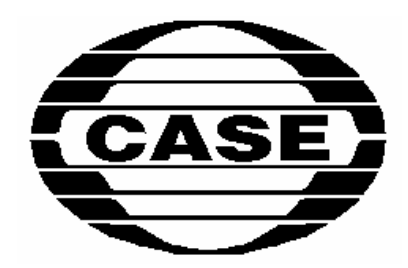

Center for Social \& Economic Research

\title{
FISCAL POLICY IN THE SLOVAK REPUBLIC
}

by

\section{Stefan Adamec}

National Bank of Slovakia

Warsaw, May 1995 
Materials published in this series have a character of working papers which can be a subject of further publications in the future. The views and opinions expressed here reflect Authors' point of view and not necessary those of CASE.

Paper financed by the Ford Foundation (grant No: 930-1199)

C) CASE Research Foundation, Warsaw 1995

ISBN 83-86296-39-9

Editor:

CASE - Center for Social \& Economic Research

00-585 Warszawa, Bagatela 14

tel/fax (48-2) 62865 81; tel/fax (48-22) 294383 


\section{INTRODUCTION}

On 1st January 1993, the independent Slovak Republic (SR) began to exist. During 1993 a democratic political system was created. It is a parliamentary democracy with a president at its head. The functions of the president were created and instituted, the Constitutional Court and Supreme Supervision Office were established. They began to create the relations determined by the constitution between the parliament (the National Council of the SR), government, president and judicial power. The functioning of the new state began to be confirmed by the issuing of new legislative norms and laws.

Starting the incorporation of the SR into international structures was an important factor in the political life of the SR. The SR became a regular member of the Council of Europe, and signed a treaty on the SR becoming an associate member of the European Union.

The specific factors of internal political development did not adversely affect the tendency to continue with the transformation process in the economy and society. The SR fully succeeded in maintaining the high level of liberalization of prices and economic relations, already achieved in the former Czecho - Slovak Federal Republic. The liberalization of foreign trade and the associated internal convertibility of the Slovak currency were maintained. In the context of the adopted conception of privatization, standard methods of privatization, justified by the specific characteristics of the Slovak economy, began to be implemented. This led to a slowing down of the progress of privatization of large and medium sized companies. The main role of macro-economic regulation was maintenance of internal and external balance. During 1993, the neutral monetary policy of the central bank, and the restrictive budgetary policy of the government, worked in favour of macro-economic stability. The absence of wage regulation, abolished under the influence of the trade unions, during this year, interfered with the stabilizing macro-economic tendencies.

Problems and complications appeared in the progress of the transformation process, but the political groups did not take this as a reason to interrupt the process.

\section{The Transformation Process}

The state achieved by the economic and social transformation, in the first year of the existence of the SR, shows a clear movement of the economy towards the conditions of a market economic system, and at the same time an existing and accepted limitation resulting from the continuing transformation recession. The progress of the transformation process, on the legislative and institutional level is firmly connected with the defined economic and political programme of the government. The basic transformation legislation, was taken over from the former Czecho - Slovak Federal Republic, with moderate amendments to the systematic content. At the same time, they were continually supplemented with further legal norms, needed for undertaking the specific features of the transformation process in Slovakia. 


\section{The Transformation of Property Rights}

The transformation law on the conditions for the transfer of state property to other persons, regulates and determines the main principles of the transformation of property rights, valid for economic organizations. Further laws regulate the conditions for the transformation of cooperative organizations, the transfer of state property to local government, restitution claims (for the years 1948-1989), and the ownership of flats and non-residential premises. An amendment to the transformation law solves the possibility of changing the methods of privatization, proposed in the privatization process for the Ministry for the Administration and Privatization of the National Property of the SR.

\section{Liberalization of Prices}

Price regulation is applied in the major items of fuel and energy products, water, postage and telecommunications, rent, health, public transport, public investment, and state intervention purchase of agricultural products. A new regulation of prices, energy, public transport and rent is expected. At present, perhaps $95 \%$ of prices in the SR are liberalized.

\section{Liberalization of Foreign Trade}

The foreign trade of the SR is almost completely liberalized. The liberalization of foreign trade, already introduced in the federal state up to 1991, as well as three devaluations of the currency, resulted in a widening of the number of bodies concerned with foreign commercial activity. With the introduction of internal convertibility of the currency, this led to a flood of goods that were non- standard, or did not correspond to the norms. Price liberalization enabled the projection of the high price of inputs into the prices of domestic products, which negatively influenced the restructuring efforts of domestic producers.

The conception of foreign trade includes a Programme for the Support of Exports of the SR, which aims to influence the export performance of the economy, with the help of the creation of international economic conditions (commercial payments agreements) for the development of foreign trade, and the creation and implementation of conditions for the development of a pro-export orientation in the business sphere. The system of the protection of the internal market has a short term character, and applies to a limited range of goods and services. It respects the principles of liberalization of foreign trade, and does not have a discriminatory or prohibitive character. It supports the structural adaptation of the productive sphere, respects international rules and prescriptions, and uses the instrument of contractual and autonomous resources of commercial policy, supplemented by the foreign currency measures of the central bank. It assumes securing protection of the domestic market, by customs, non-tariff and license policy, in harmony with the rules of the GATT, WTO and IMF. Regulation of some payments to foreign currency foreigners was temporarily applied, in the interest of stabilizing the foreign currency reserves of the banking system. In the interest of accelerating the restructuring and modernization of the business sphere, import of new technology and equipment to the SR is free of customs duties. The commercial part of the Central European 
Agreement on a free trade zone between Slovakia, the Czech Republic, Hungary and Poland, has been in operation since the beginning of 1993.

\section{Reform of the Tax System}

On the basis of the tax reform carried out up to the date of origin of the SR, the tax system of the SR consists of value added tax, consumption tax, income tax on individuals and corporate bodies, and other standard direct taxes. In 1993, payers of value added tax, the rates of which are set at $6 \%$ and $25 \%$, had an annual turnover of 6 billion Sk. Income tax on individuals has 6 bands, in the range from 15 to $47 \%$. The untaxable part of the tax base is 21,000 Sk. Tax on profits has a single rate of $40 \%$.

In the framework of the Slovak tax system, it is possible to submit a claim for tax relief, in the interest of supporting specific economic aims, such as entry of foreign investors, regional development, employment policy and the development of small businesses. However, so far a high level of tax evasion has been characteristic of the application of the tax system.

Amendment of the law on income tax, leading to a reduction of the highest rates of income tax on individuals, and a reduction of the tax base for newly established businessmen, is being considered for the near future. The unification of rates of value added tax, and widening of the number of payers of value added tax, by a reduction of the lower threshold to a turn over of 3 million Sk. is also being considered.

\section{Social Security}

In the year of origin of the SR, the system of social security functioned on the basis of the National Insurance of the SR, which involved a fund for obligatory health, medical and pension insurance. In 1993, the state budget secured the functions of the fund. In 1994, National Insurance was transferred to an independent economic basis. The insurance contributions are set at $11 \%$ of the measuring base for employees, at $35 \%$ for employers, and at $46 \%$ for people who are independently productively active. The creation of a pluralist system in the SR is considered for the future.

Medical insurance covers employees who cannot work as a result of illness, the birth of children and the need for treatment of sick members of the family. Employees receive $70 \%$ of their wages for the first three days of sickness, and $90 \%$ for further days. The maximum payment is $180 \mathrm{Sk}$ per day. Payment is made either by companies or the state.

The policy of health insurance involves a programme of health care, which assumes an inter-disciplinary approach to health care, with regard to the influences of the environment and employment on health, a strategy of permanent prevention and education, and a strategy of preventive vaccination. The aim is to decentralize ownership, management, and financing of the health and social services on the level of local government organs.

The pension system is effective up to the day of going onto a pension. A pensioner obtains a full pension after 25 years of employment, on reaching the age of 53 - 57 years for a women (modified by the number of children), and 60 years for men. The pension is 
calculated on the basis of income in the best five years of the last ten years before retirement. The maximum pension is set at 4,100 Sk, and the minimum at 1,980 Sk.

\section{The Social Programme}

Tripartite negotiations are the means for adjusting wage and social incomes to the growth in the cost of living. The tripartite negotiations resulted in various adjustments, including a change in the minimum salary to $2,450 \mathrm{Sk}$ per month, increased sums for social care (personal expenses, plus household expenses) to 1,350 + $650 \mathrm{Sk}$. People whose pensions do not reach the level of the living minimum, can draw a special supplementary social care benefit.

In 1993, the development of pay was not regulated, with the exception of organizations in the budgetary sphere. In 1994, pay regulation was revived, state equalizing contributions were abolished, and child benefit payments were changed according to the economic situation of the family.

The employment fund carries out an active policy for employment, through financing the material needs of job applicants. The level of obligatory contributions to this fund, were set at $1 \%$ for employees, $3 \%$ for employers, and $4 \%$ for the self employed, calculated from the measuring base. The right to unemployment benefit lasts 6 months, 3 months at the level of $55 \%$ of the applicant's former pay, a further 3 months at a level of $50 \%$, and $75 \%$ in a period of requalification.

In 1993, an active policy of employment was applied through programmes of creating socially useful jobs and publicly beneficial works, by means of reduced working obligations, support for job applicants with reduced working ability, recent school leavers, and the introduction of requalification programmes.

\section{Development of Financial Institutions}

By the day of the origin of the SR, a central bank, the Národná Banka Slovenska (National Bank of Slovakia - NBS) was established by a law of the National Council of the SR, as the central bank of the SR, with legal sovereignty on 1st January 1993. Its establishment was caused by the division of the Czecho - Slovak Federal Republic into two independent states, the SR and the Czech Republic. In the Federal Republic, the central bank was the State Bank of Czecho - Slovakia (SBCS). The executive component of the SBCS on the Slovak territory of the federal state, was the Republic Centre of the SBCS for the SR, with its headquarters in Bratislava, and 3 branches, situated in Bratislava, Kosice and Banská Bystrica respectively.

The law determines that the NBS

* is the central or currency issuing bank of the SR,

* has its headquarters in Bratislava,

* is a corporate body, not registered in the commercial register,

* in property relations, concerning its own property, it has the position of a company, 
* when issuing generally binding legal prescriptions, to the extent defined by law, it has the position of a ministry of the SR and other central organs of the state administration, in accordance with article 123 of the Constitution of the SR.

The organization and management of the NBS has two levels. The main units are the headquarters and the branches. The branches in Bratislava, Kosice and Banská Bystrica secure the performance of selected functions of the central bank, in the territorial regions of the SR.

The branches have established departments. The Institute of Banking Education in Bratislava is a special purpose unit, securing the education of employees of the central bank, and of commercial banks active in Slovakia.

The NBS is a legally independent institution. The main role of the NBS is to secure the stability of the Slovak currency. It is the responsibility of the NBS to determine monetary policy, issue bank notes and coins, manage monetary circulation, supervise the performance of the banking activities of the commercial banks, and carry out other activities flowing from the law. The law requires the NBS to support the economic policy of the government of the SR.

Every six months, the NBS is obliged to submit a report on financial developments to the National Council of the SR. The NBS represents the SR in international financial, and secures fulfillment of the tasks resulting from this representation. The NBS submits proposed laws to the government in the areas of currency and monetary circulation. Together with the Ministry of Finance of the Slovak Republic, it submits proposed laws about foreign currency and banking to the government.

According to law, the organs of the NBS are the Bank Board of the NBS and the Directorate of the NBS.

The Bank Board is the supreme managing organ of the NBS. It determines monetary policy, and the instruments for its implementation, and decides on the monetary measures of the NBS.

The members of the Bank Board are the governor, two vice- governors, two chief directors of the NBS and three other members. The president of the SR appoints and dismisses the governor and vice-governors, on the proposal of the government of the SR, after authorization by the National Council of the SR. The governor represents the NBS externally.

The Directorate is the executive organ of the NBS. It is responsible for carrying out the decisions of the Bank Board. The members of the Directorate are a vice- governor, appointed by the governor, and the chief directors of the NBS.

The governor, vice-governors and chief directors will hold their offices for 6 years. Other members of the Bank Board will hold office for 4 years. Membership of the Bank Board is limited to two periods.

The governor of the NBS participates in meetings of the government.

After its creation, the banking sector developed dynamically. A network of regional and specialized banks has been created. The banking sector is beginning to orient its development towards strengthening its capital position. Since the beginning of 1994, the foundation of a bank has required basic capital amounting to a sum of 500 million Sk in 
the form of a cash deposit. By the end of 1993, 17 domestic banks, 9 branches of foreign banks and 7 offices of foreign banks were operating in Slovakia.

By the middle of 1994, 19 commercial banks and 10 branches of foreign banks were active in the SR. Seventeen banks and 2 state financial institutions were registered as joint stock companies. The headquarters of 16 of these banks are situated in Bratislava, with one each in Zilina, Banská Bystrica and Kosice. Nine branches of foreign banks had headquarters in the Czech Republic, and one branch had its headquarters in Holland.

The equity of the banking sector amounted to 14.2 billion Sk, including 1.8 billion Sk of foreign participation in equity.

Among the 17 commercial banks, 13 had banking licenses for banking activities with limitations to the range of banking activities. Full licenses for foreign currency operations were issued to 9 commercial banks.

Development also occurred in the establishment and functioning of financial institutions (investment companies, and privatization investment funds) and the functioning of the capital market. The Bratislava Stock Exchange, the Bratislava Options Exchange and the joint stock company RMS-Slovakia, which deals in shares from the coupon privatization, represent the organized part of the capital market. The unorganized capital market is developing in a way which is flexible and capable of action.

In 1993, the nominal value of the capital transactions on these markets amounted to more than 11.5 billion $\mathrm{Sk}$, more than a seventh of the total value created in the privatization. The total number of transactions was 160,000.

The Slovak capital market would work better, if trading was done at one trading place, and prices could be made known in real time, with general accessibility for the public. Limitation of information, consistent legislation and access to the Slovak market in shares is characteristic of the present situation.

In the process of privatization, the Slovak government created a special institution: The Centre for Securities. This is the central register for all shares in the possession of Slovak companies and secures all transfers between registered holders. A Slovak or foreign entity cannot secure the transfer of Slovak shares without use of the Centre for Securities, as the transfer and registering agent. The Centre for Securities can significantly assist the development of the Slovak capital market. The Slovak capital market must attempt to make the connection between the Centre for Securities and other participants in the market. Exchanges and brokers should have direct access to the data of the Centre for Securities, so that it can immediately freeze the account of a share holder in real time.

Investment funds carry out the greatest bulk and commercial transactions on the Slovak capital market. The present lack of transparency of the capital market is advantageous to the investment funds. Share holders in a fund do not have the possibility to find out, at least approximately, the value of the fund shares, and the substantial part of managing the fund is left to the manager of the fund. Improvement of the method of trading by investment funds may change the unfavourable position of the stock exchange market, in relation to the non-stock exchange market. This could lead to a greater identification with the principles of responsibility and accessibility, by which investment funds are managed on developed capital markets. The present absence of effective regulation on the capital market, brings a situation of trade between funds, which occurs 
on the basis of undervaluation of one side against the other, instead of advantageous reciprocal service. The problems of carrying out operations with options, and seeking an answer to the question of whether it is possible, in the conditions of the Slovak capital market, to trade in securities and security derivatives on one or on several exchanges, and what should be the framework of products on the market in share derivatives, are further questions to be solved in the development of the capital market in Slovakia.

\section{Privatization of the Business Sector}

Lesser privatization may be considered complete. The result of lesser privatization is 9,676 privatized units, and an income from their sale amounting to 14.5 billion Sk. In the middle of 1993, the first stage of greater privatization was finished, in which 853 state joint stock companies were privatized. In 503 cases, the coupon method was used. The proportion of private organizations to the total number of organizations in Slovakia is more than $75 \%$.

Lesser privatization applied to the smaller operational units of state enterprises. The subjects of transfer are assets and stocks without claims, commitments and employees. Sale at public auctions was applied as the method of transfer of state property to other persons. The sales concerned mainly operational units in the sectors of shops, tourism, restaurant services and small operational units of industrial companies. Non-functional units were put into liquidation.

In the first completed wave of greater privatization, the greater part of the property, amounting to 154 billion Sk invested in joint stock companies. An insignificant proportion of the shares were sold by standard methods, and a major part of the shares are owned by the Fund of National Property. The joint stock companies are controlled by private share holders.

The first wave of coupon privatization was institutionally secured on the federal level. The Federal Ministry of Finance secured the whole process, and established the Centre for Coupon Privatization for this purpose. The process of privatization was legislatively approved by a decree of the government of the CSFR no.383/1991 Col., on the issuing and use of investment coupons. 503 joint stock companies with their headquarters in the SR were assigned to the first wave of coupon privatization. Their equity amounted to 117.6 billion Sk. Shares with the nominal value of 86.9 billion Sk were offered in the coupon privatization. 2.59 million inhabitants of the SR participated in the coupon privatization. Among them two thirds of the people participated by means of privatization investment funds. In the first wave of coupon privatization, $92.8 \%$ of the offered shares were sold. Among the joint stock companies with headquarters in the SR, all the offered shares in 98 companies were sold, and the majority of shares in 456 companies were sold. The privatized joint stock companies held general meetings, and the share holders applied their rights of ownership, and control the joint stock companies.

During privatization, the principle was applied of not making the privatization of the enterprises dependent on their restructuring. Neither was any technological and financial restructuring of the companies intended for privatization, carried out. Only an organizational restructuring was done at various business entities.

Privatization investment funds became active in the process of privatization. Their activity is regulated by law no.248/ 1992 Col. on investment companies. According to it, 
investment funds could participate in the securities market, either directly, or by means of account share funds.

The participation of new investment and share funds is proposed for the second wave of coupon privatization, with certain legislative limitations concerning the structure of their portfolios of securities.

Foreign technical aid is used in organizing the process of privatization. The programme PHARE is used to pay the costs for the privatization and restructuring projects, and the expenses of various experts and advisors.

The programme US - AID is also used in working out the programmes of restructuring and privatization of selected enterprises from the arms industry.

Foreign investment and the creation of companies with foreign ownership participation are an important part of the restructuring of the business sector. In 1993, foreign capital was active in more than 4,500 organizations. Organizations with exclusively foreign capital made up one third of these. Companies from Austria, Germany, the USA and the Czech Republic have the greatest share in the total volume of foreign capital.

In 1993, the document Specification of the Further Approach to the Process of Privatization in the SR, was applied. It defined the direction of the privatization policy of the government, to the differentiation of privatization methods, on the basis of the preferred socio-economic and strategic aims of the state. Standard methods are assumed for the privatization of smaller enterprises. A strategy of the use of standard methods in combination with the methods of creating employee joint stock companies in the second round of coupon privatization was marked out for the future.

An amendment to the law on bankruptcy and liquidation (Law on Bankruptcy) has been prepared as a significant stimulus to restructuring of the business sector. The amendment sets a three month time limit for agreed action, before declaring bankruptcy. So far the law on bankruptcy has been applied only occasionally in the SR.

To improve the quality of the controls on the financial management of companies, an amendment to the law on state enterprises was passed. It obliges enterprises to deposit financial resources in only one commercial bank. In the framework of restructuring, the problems of converting the arms industry were also solved. A joint stock company with $100 \%$ state ownership, was established to secure sale of surplus weapons and return of the financial resources invested in arms production. To fulfill the obligations of converted enterprises intended for privatization, resources of the Fund of National Property amounting to 2.9 billion Sk were used.

The National Agency for the Development of Small and Middle Sized Companies is engaged in specific activities to support the development of the economic activities of small and medium sized companies. 


\section{CLASSIFICATION AND PREPARATION OF THE STATE BUDGET}

\section{A Brief History of the National Budget of the Slovak Republic}

The socio-economic changes that started in Slovakia in 1989 were reflected in the country's economic development as well. The conditions for the budget performance of the Slovak Government changed considerably in the period between 1989 and 1994. It is possible to delimit three basic phases of development:

-1989-1990 preparation for economic transformation,

-1991-1992 implementation of the economic reform under federal conditions,

-1993-1994 implementation of the economic reform under the conditions of an independent republic.

The state budget for 1989 was set up under the conditions of central planning and the existence of three inter-bound budget areas (a federal and two republican areas). The financial resources used to be concentrated in the federal budget, and reallocated to the republican budgets in the form of subsidies. In 1989, transfers to the State budget of the Slovak Republic amounted to Kcs 53.7 billion, while its own revenues were at the level of Kcs 37.6 billion. The actual budget performance of the Government showed some signs of imbalance, which resulted in a budget deficit. This development was due to the overassessment of some revenue items, the underestimation of budget expenditures (especially in the field of social expenditures), and to the inadequate reserve formation. In 1989, the State budget of the Slovak Republic reached a total deficit of Kcs 1.4 billion (the Czech Republic's budget recorded a deficit of Kcs 1.3 billion, that of the federal budget amounted to Kcs 0.8 billion). Both the federal and the republican fiscal deficits were covered by funds from the financial assets of the federation. In this connection, an important fact is that the recorded deficit was artificially reduced by Sk 1.6 billion by using the financial reserves generated by extrabudgetary financial operations during the previous years (a similar method was used in the case of the State budget of the Czech Republic and that of the federation). The national budget of the Slovak Republic ended with a deficit of Kcs 3.0 billion.

In 1990, some principal changes were made in the budgeting system of the Government in connection with the preparation for a radical economic reform. The changes in government budgeting included structural changes, a gradual price liberalization, the abolition of the unfavourable turnover tax, the introduction of stricter criteria for granting credit and loans, and a restrictive and antiinflationary financial policy. The collapse of traditional markets is accountable for the limited possibilities of raw material imports, and for the loss of vital marketing facilities. The Slovak economy was most seriously hit by the negative consequences of arms conversion, the decline in the output of mining, construction, and agricultural industries. The performance of the State budget was also affected by systemic measures taken in connection with the organizational restructuring and demonopolization of the economy (reduction of state subsidies, a restrictive fiscal and credit policies, the devaluation of the Czechoslovak 
crown against fully convertible currencies, and the general consumer-price increases, etc.)

For the first quarter of 1990, a provisional budget was set up. The definite version of the State budget for 1990 was approved only in February. In this connection, the Federal Government and the Government of the Slovak Republic approved a whole series of economic measures (increases in the prices of crude oil, petroleum products, fuel, and energy; increased tariffs for freight and passenger transport, increases in the retail prices of foodstuffs and public catering). At the same time, a state balancing allowance was introduced as compensation for increases in the costs of living in the amount of Kcs 140 per capita (since July 1990). The Czechoslovak crown was three times devalued against fully convertible currencies (by $18.6 \%$ on 8 January, by $55.3 \%$ on 15 October, and by $15 \%$ on 28 December 1990). As these measures were directly affected by the State budget, its revenue and expenditure sides were modified, together with changes in the policy of granting federal subsidies to the Slovak Republic, and the percentage of the SR in the total revenue from turnover tax (a decrease from 29\% to $23 \%$ ). Although the projected revenues were exceeded, the State budget ended with a deficit of Kcs 0.5 billion. This development was due to the fact that most of the expenditure items had been exceeded (except for subsidies granted for financial and economic instruments in foreign trade).

In 1991, the Government's approach to the drafting of the national budget of the Slovak Republic differed from those in the past. It reflected the changed position of the financial policy in the process of economic reform. The main feature of the 1991 state budget was its restrictive character, which was reflected in the fact that the budget had been drafted with a planned surplus. During the preparation of the State budget, however, the impacts of price liberalization were underestimated. This later determined the fulfilment of both the revenue and the expenditure sides of the State budget. For the first time, the republican budgets were set up with a certain touch of independence. However, the external as well as the internal factors of development were forecast quite inaccurately, which had a serious effect on the fulfillment of the goals of the Government's financial policy.

The expected revenue base of the State budget of the Slovak Republic was considerably affected by the new rules of government budgeting and the results of negotiations on the division of powers between the federation and the two republics. The ratio to be applied at the division of federal revenues from turnover tax, transfers from profits, transfers from the banking and the insurance sectors, and transfers from agricultural profit (25\% to the Slovak Republic, $40 \%$ to the Czech Republic, and $35 \%$ to the federation). Apart from this, the republics approved the principle of the division of revenues from income tax and the agricultural tax on wages and premiums (87\% to the republican budget, and $13 \%$ to the local governments' budgets in the Slovak Republic). The individual chapters of the State budget included special purpose funds associated with the consequences of the economic reform (Kcs 2.6 billion for unemployment, Kcs 1.4 billion for requalification training, and $\mathrm{Kcs} 3.4$ billion for the valorization of pensions).

The implementation of budgetary policy in 1991 must be judged in the context of Slovakia's general economic development. In the course of 1991, the first consequences of economic, political, organizational, and institutional changes began to appear, 
considerably influencing the budgetary policy of the Slovak Republic, owing to the poor preparedness of the local economic entities for these changes. To mitigate the negative effects of the radical economic reform on the population, it was necessary to strengthen the social aspects of development to the detriment of subsidies granted to the enterprise sector.

As a result of the impacts specified above, the national budget of the Slovak Republic recorded a deficit of Kcs 10.2 billion in 1991, while the modified budget expected a surplus of Kcs 0.1 billion. In the revenue side of the budget, the projected turnover tax revenues were not fulfilled, mainly as a result of stagnation in the domestic market, caused by the liberalization of prices and the reduced purchasing power of households. Transfers by state- owned enterprises also remained behind the budgeted amounts as a result of the economic decline, the loss of traditional markets, wage restriction, and the high rate of unemployment. The expenditures exceeded their budgeted level owing to the greater-than-expected investment costs of budgetary organizations (for the establishment of new bodies of state administration, and the financing of the needs of health service and education), and the non- investment costs of the non-productive sector (associated with the new conditions of social development in Slovakia).

The conception of the 1992 State budget of the Slovak Republic was affected by the following economic factors:

- the earnings of economic entities (including the development of money incomes of households), 1991 ,

- the general price level and certain positive results in holding down inflation in

- the decline in capital investments in industry, agriculture, and in the tertiary sector,

- the traditionally high level of dependence of Slovak commodity exports on the former Council for Mutual Economic Assistance, and the problems arising from the unfavourable economic development in these countries,

- development in the field of unemployment as a result of structural changes in the production base, and the growth of population at the beginning of 1970ies.

Apart from this, the State budget was designed with regard to the tasks and priorities of the Government's financial policy, especially the slowdown of economic decline, the maintaining of a minimum rate of inflation, and the continuation in the process of transformation. In the field of fiscal policy, the Government tried to find a common approach to the preparation of all three budgets (to apply a system of common revenues, or a territorial principle, a way to arrange the relations between the republican and local budgets, the balance of these budgets, etc.). These questions were finally solved during the negotiations held on the level of prime ministers and finance ministers in the presence of the President of the former Czech and Slovak Federal Republic. The parties agreed upon the principle of a balanced national budget and the division of the so- called "common revenues" in the following ratios: $35 \%$ to the federation, $41.5 \%$ to the Czech Republic, and $23.5 \%$ to the Slovak Republic. It was obvious from the beginning that the declared equilibrium of the State budget was only a formal one. This became evident from the fact that funds had been set aside for financing the construction of housing projects, to be covered by a subsequent issue of government bonds. The state budget 
were not designed to finance the completion of construction work on the hydroelectric scheme at Gabcikovo, postponing the solution of this problem until a later date.

After some negative experience with the performance of the State budget in the previous years, the Government adapted some regulatory measures applicable to the expenditure side of the budget at the beginning of 1992. However, the savings on expenditures failed to compensate for the loss of revenues, so the State budget showed a slight deficit during the year. In December, however, the regulatory system broke up completely, resulting in an uncontrolled drawing of budget expenditures. This was the main cause of the Kcs 7.9 billion budget deficit, together with the low level of budget revenues. The revenue side of the budget was most affected by the non-fulfillment of revenues from turnover taxes, as well as corporate profit tax revenues. The so-called "common revenues" were transferred from the whole CSFR to the federal budget, and then reallocated to the individual areas of the republican budgets according to the agreed ratio. The total expenditure was exceeded mainly by increased drawings by the nonproductive sector, and drawings to finance the completion of the hydroelectric project at Gabcikovo. For this purpose, the Government floated an issue of government bonds in the volume of Kcs 4.5 billion in December 1992 in accordance with the relevant Act of Parliament. Of this issue, however, only Kcs 2.0 billion worth of bonds were placed successfully on the capital market, and the remaining amount had to be covered from budgetary resources.

The birth of the independent Slovak Republic on 1 January 1993 brought about a significant change in the performance of the State budget. Instead of three inter-bound budget areas (federal and two republican budgets), this was the first time that the State budget of the Slovak Republic was applied in a sovereign state. Along with internal factors (Slovakia's sovereignty, the introduction of a new tax system, unemployment, inflation, etc.), the budget performance was also affected by external factors (worldwide economic recession, loss of traditional markets, etc.). Under these conditions, at a considerable degree of uncertainty about the characteristics of the new economic environment, the chief objective of the Government's financial policy was to ensure a sustainable level of inflation. The considerations were based on an annual rate of inflation ranging from 13 to $20 \%$ on condition that the Slovak currency would not be devalued against fully convertible currencies and that there would be only minimum price increases in the world markets. The rate of unemployment was estimated at 14 to $18 \%$ with considerable differences in the individual regions.

The most disputed question was the possibility of achieving a balanced state budget. Despite objections raised by several economists, the Government approved the conception of achieving a balanced state budget. This decision was based on the following grounds:

a) under the political agreements concluded between the Czech and Slovak republics, equal condition were to be created in both republics for the establishment of a monetary and customs union. In the area of budget management, this meant that a balanced national budget had to be achieved in Slovakia (as well as in the Czech lands).

b) an effort to prevent the further growth of fiscal deficit by exerting pressure on the observance of budgetary discipline, and the economical use of the available resources,

c) prospects for future development (the repayment of debts by future generations), 
d) the impacts of the budget deficit on the Government's monetary policy.

However, the actual development considerably contravened these expectations. Over the course of 1993, periods of relative stability alternated with periods marked by a growing budget deficit. The revenue side of the State budget was negatively influenced by low retirement, sickness, and health insurance payments, and contributions to the employment fund, and insufficient revenues from corporate profit tax, value added tax, and excise tax.

The expenditure side of the budget was affected mainly by the higher-than-expected volume of transfers to households (due mainly to the payment of state balancing allowances, which were covered by budgetary means only in the first two months of 1993, despite the fact that its payment was approved by Parliament for the whole year), by expenditures for the public consumption of the population and the State (health service, foreign service, and national security), and by expenditures associated with the national debt service (which were underestimated when the budget was drafted).

The combined effect of these factors caused that the national budget reached a total deficit of Sk 23.0 billion by 31 December 1993. According to the relevant Act of Parliament, the deficit was to be covered by an issue and subsequent sale of government bonds. However, this part of the budget deficit is to be increased by Sk 5.8 billion, the amount credited to Slovakia by the Czech Republic through the clearing account in accordance with the Clearing Agreement signed by the two republics.

The State budget for 1994 was drafted with a projected deficit of Sk 14.0 billion, which was to be used as a factor mobilizing the formation of resources for investment and development programmes. Another significant change compared with the situation in 1993 was the separation of the National Insurance Corporation (responsible for the management of the pension, sickness, and health insurance funds for the population) from the State budget, as a result of which the budget revenues and expenditures dropped by almost one third. The state budget design for 1994 was based on the following assumptions:

- a zero economic growth (the Gross Domestic Product in constant prices at the level of 1993);

- renewed rate of privatization (a $28.6 \%$ increase in the private sector's share in GDP formation);

- a $12 \%$ rate of inflation (growth rate reduced by $50 \%$ compared with that of 1993);

- a rate of unemployment below $17 \%$;

The priorities of the state budget for 1994 were:

- to cover the financial needs of the State;

- to have a significant share in the process of economic transformation;

- to create more demanding conditions of access to public finance for all economic sectors;

- to play an anti-inflationary role in the economy (to maintain the internal and external debt of the government at an acceptable level);

- to support the priorities of the Government's economic policy; 
- to help rationalize the organizational structures of the executive bodies of central and local governments;

- to create conditions for maintaining social order.

\section{Structure of the 1994 State Budget}

\section{R E V E N U E S}

A. TAX REVENUES

Direct tax

- Corporate profit tax 1)

- Personal income tax

of which:

- on wages 2)

- on entrep. activity

- on dividends/interest

Indirect tax

- Value added tax

- Excise tax

Other tax revenues

B. NONTAX REVENUES

- Customs duties

- Disbursements to the State budget

- Interest on government assets

- Payments on government loans

- Other nontax revenues
Sk billions

97.3

38.7

26.7

12.0

5.2

3.8

3.0
$\%$ of total

78.2

31.1

21.5

9.6

4.2

3.0

2.4

46.5

57.9

30.6

$19.8 \quad 15.9$

$0.7 \quad 0.6$

27.2

21.8

$\begin{array}{ll}4.4 & 3.5\end{array}$

$6.0 \quad 4.8$

$0.7 \quad 0.6$

$6.4 \quad 5.1$

$\begin{array}{ll}9.7 & 7.8\end{array}$

124.5

100.0

TOTAL REVENUE

Note:

1) The total revenue is $\mathrm{Sk} 28.3$ billion, of which $5.87 \%$, i.e. Sk 1.6 billion belongs to local budgets;

2) The total revenue is $\mathrm{Sk} 7.4$ billion, of which $29.92 \%$, i.e. Sk 2.2 billion belongs to local budgets;

\section{EXPENDITURES}

A. TRANSFERS TO HOUSEHOLDS

Non-systemic social transfers

Transfers to insurance funds

Payments of social benefits
SK billions

22.9

11.7

7.6

3.6

24.7

16.2

1.9

$\%$ of total

B. PUBLIC CONSUMPTION (POPULATION)

Education

Health service 


\begin{tabular}{|c|c|c|}
\hline Culture & 2.1 & 1.5 \\
\hline Other & 4.5 & 3.2 \\
\hline C. PUBLIC CONSUMPTION (GOVERNMENT) & 40.1 & 29.0 \\
\hline Defence and security & 10.4 & \\
\hline Justice administration & 0.6 & 0.4 \\
\hline Other admin. bodies & 4.5 & 3.3 \\
\hline Other expenditures & 20.6 & 14.9 \\
\hline D. NATIONAL DEBT SERVICE & 23.4 & 16.9 \\
\hline E. HOUSING DEVELOPMENT & 2.5 & 1.8 \\
\hline F. SUBSIDIES TO LOCAL GOVERNMENTS & 1.0 & 0.7 \\
\hline G. SUBSIDIES TO ENTERPRISES & 17.0 & 12.3 \\
\hline H. TRANSFERS TO THE PUBLIC SECTOR & 6.9 & 5.0 \\
\hline T O T A L EXPE & 138.5 & 100.0 \\
\hline STATE BUDGET DEFICIT & -14.0 & \\
\hline
\end{tabular}

Note: The individual items of the State budget are specified in Chapters IV and V of this report.

\section{Structure of Local Budgets for 1994}

A decisive source of revenues for local budgets are taxes and local rates imposed, collected, and administered by local governments, and resources generated by the economic activities of local governments. The expenditures of local governments are partly covered from tax revenues collected at republican level. Direct financial transfers from the State budget to local budgets are used for the administration of small local communities (with a population below 5,000) and for the investment and non- investment needs of local public transport.

REVENUES Sk billions $\%$ of total

$\begin{array}{lcr}\text { A. LOCAL TAXES AND RATES } & 3.8 & 29.7 \\ \text { Real estate tax } & 2.3 & 17.9 \\ \text { Local rates } & 0.7 & 5.5 \\ \text { Administrative fees } & 0.1 & 0.8 \\ \text { Other fees } & 0.7 & 5.5 \\ & & \\ \text { B. INCOME FROM LOCAL PROPERTY } & 2.3 & 18.0 \\ \text { Earnings of local organizations } & 0.5 & 3.9 \\ \text { Proceeds from the sale of property } & 1.0 & 7.8 \\ \text { Revenues from local property } & 0.1 & 0.8 \\ \text { Revenues from local activities } & 0.7 & 5.5\end{array}$




\begin{tabular}{|c|c|c|}
\hline C. SHARE OF STATE TAX REVENUES & 4.3 & 33.6 \\
\hline Share of personal income tax & 2.2 & 17.2 \\
\hline Share of corporate profit tax & 1.6 & 12.5 \\
\hline Road tax & 0.5 & 3.9 \\
\hline D. OTHER REVENUES & 1.4 & 10.9 \\
\hline E. SUBSIDIES FROM THE STATE BUDGET & 1.0 & .8 \\
\hline TOTAL REVENUE & & \\
\hline
\end{tabular}
EXPENDITURES
Sk billions $\%$ of total

A. EXPENDITURE ON LOCAL GOVERNMENT

\begin{tabular}{|c|c|c|}
\hline FUNCTIONS & 9.3 & 72.7 \\
\hline B. SUBSIDIES TO LOCAL ENTERPRISES & 0.6 & 4.7 \\
\hline C. FINANCIAL TRANSACTIONS & 0.4 & 3.1 \\
\hline \multicolumn{3}{|l|}{ D. EXPENDITURES ON DEVELOPMENT } \\
\hline PROGRAMMES & 2.2 & 17.2 \\
\hline \multicolumn{3}{|l|}{ E. INVESTMENT SUBSIDIES FOR LOCAL } \\
\hline PUBLIC TRANSPORT & 0.3 & 2.3 \\
\hline TOTAL EXPENDITURE & 12.8 & 100.0 \\
\hline
\end{tabular}

\section{Extrabudgetary Funds}

A part of the economic policy followed by the Slovak Republic is a system of state funds, established for the purpose of financing specific extrabudgetary projects. The reason for the establishment of state funds is to partially unburden the government budget and to concentrate financial resources for the funding of selected extra- budgetary projects. A state fund is established on the basis of the Act of Parliament with the aim of financing a particular project, and may not be used for other purposes. The fund's expenditures are limited by its resources, which may not be exceeded. The fund is administered by the central body of state administration according to law. The scope of activity of a state fund is specified by its statute, which is approved by the central government. The draft of a statute is submitted to the Government by the body in charge of the fund's management. Apart from this, the managing body of the state fund presents the draft budget for the relevant fiscal year, a list of assets and liabilities, and the financial statement to the Ministry of Finance. The liabilities of the fund are nor guaranteed by the government. 


\section{The System of Government Funds in 1991 - 1993:}

\section{Environmental Protection Fund}

The Fund's major source of income is formed by penalties imposed for air and water pollution, and for the unofficial offtake of underground water. The resources of the Fund are used for financing the construction of water mains, sewage disposal plants, and sewerage systems, for the solution of technical failures in water supply, protection of water from industrial pollution, for the installation of gas fittings in boiler houses, and for the purchase of technological equipment for the disposal of secondary raw materials and industrial waste.

\section{Cultural Development Fund}

The Fund's most important source of finance is formed by subsidies from the State budget, and by the earnings of budgetary organizations operating in the field of culture. The Funds spends its resources for the reconstruction and utilization of cultural monuments, historical literary funds, the preservation of cultural values and works of art of all-national importance.

\section{Water Resources Development Fund}

The Fund has been established to support development projects in the field of water economy, hydrogeological prospecting, and to cover the costs of technical failures of hydraulic engineering structures. At present, the Fund does not function properly, there are minimal changes in its revenue and expenditure accounts.

\section{Forest Development Fund}

The Fund's only source of income is formed by subsidies from the State budget, which are used for the protection and plantation of forests, and for the implementation of long-term forest development projects .

\section{Market-Oriented Agricultural Production Fund}

The Fund has been established to support the adjustment of agricultural producers to the changed conditions in foodstuff markets. The Fund realizes interventional purchases at guaranteed prices, makes agreements on the realization of interventional purchases of agricultural produce, provides subsidies for exports, cooperates in filling up the government's material reserves, and proposes the level of balancing prices to eliminate the differences between import prices and domestic market prices.

\section{Agricultural Land Protection and Improvement Fund}

The aim of this fund is to ensure resources for the conservation, reclamation, and the general improvement of agricultural land. The Fund obtains its financial resources from the sale of land, and from budgetary subsidies, which are used to finance the operation, maintenance, and repairs of land reclamation structures, and the construction of new land reclamation projects.

In the course of 1994, four additional funds were established: the Physical Training Fund, the Health Fund, the Road Fund, and the Agricultural Land and Food Processing Fund. 


\section{State Financial Assets and Liabilities}

The transformation process going on in the Czechoslovak economy and the enforcement of the law concerning the division of the former federal property between the Czech Republic and the Slovak Republic represented a serious interference in the government's financial assets and liabilities. This brought changes in the Government's position vis-a-vis the banking system and the rest of the world. The following financial assets (in the amount of approx. Sk 11.5 billion) were transferred to the Slovak Republic:

- targeted crown resources obtained from the sale of foreign exchange at the times of drawing foreign loans from the World Bank, the European Community, and from the group of 24 industrial countries (G-24) in accordance with the Agreement on the Succession of Foreign Credit and Loans extended by foreign governments to the former CSFR for the support of its balance of payments;

- the federation's financial resources in the form of reserves (risk reserves to cover the risks of government loans) and special purpose funds;

- the resources of the "Republic's Fund";

- crown resources "Gifts from Abroad", earmarked for the support of reform programmes in the field of environmental protection;

- other targeted funds of the former federation (earmarked for the solution of the negative consequences of arms conversion, etc.).

On the other hand, the Slovak Republic inherited state financial liabilities from the former federation in a twofold amount (Sk 21.7 billion), in accordance with the government's liabilities with regard to government loans extended to foreign countries, and the settlement of the consequences of devaluation and revaluation of federal currency on Czechoslovak banks. These liabilities are currently credited by the National Bank of Slovakia.

\section{Social, Sickness, Health, and Unemployment Insurance}

Before 1993, the above activities had been financed from the general budget. On 1 January 1993, two new public institutions were established for this purpose: the National Insurance Corporation, providing pension, sickness, and health insurance services, and the Employment Fund, which was established to administer unemployment benefits to the jobless, and to support an active policy of employment by providing job placement services and requalification training. In 1993, both institutions were financed from the State budget; they started to operate independently only on 1 January 1994. The starting base for the formation of the National Insurance Corporation were data on average wages, numbers of workers employed in various sectors of the economy, and the earned incomes of the self-employed, as well as the number of people whose insurance is paid by the State.

The National Insurance Corporation's main source of income is formed by social insurance payments; its supplementary source of funds consists of transfers from the State budget, own resources, revenues from the corporation's own property, penalties, fees, and gifts. Insurance payments are shared by the employer and the employee. For employees, the base of assessment is the income earned in a decisive period; for selfemployed, the base of assessment is $50 \%$ of the proportional part of the personal income 
tax base. An employees is obliged to make insurance payments amounting to $11 \%$ of his assessment base, an employer covers insurance payments totalling $35 \%$ if the assessment base of his employees; while the total mandatory insurance payments to made by selfemployed and the state (for the specified group of persons) have been set at $46 \%$, of which health insurance accounts for $13.7 \%$, sickness insurance accounts for $5.8 \%$, and pension insurance accounts for $26.5 \%$ of the assessment base.

The revenues of the National Insurance Corporation are used for the following purposes:

- to cover the costs of preventive health care and basic health services;

- the payment of sickness benefits,

- the payment of pensions,

- the payment of the costs of other insurance corporations or other legal entities according to the agreements on services provided to their ensures,

- the payment of the costs of inevitable health care provided abroad,

- to cover the operating costs of the National Insurance Corporation and its establishments.

The Unemployment Fund is financed by unemployment insurance payments paid by employees ( $1 \%$ of the assessment base, i.e. gross monthly wage), employers (3\% of the assessment base of his employees, i.e. the payroll), and the self-employed and the coemployed (4\% of the assessment base). Apart from the payment of unemployment benefits, the resources of the Unemployment Fund are used for creating new job opportunities, job placement services, organizing projects beneficial to the public, requalification training, and the administration of the Fund, and the costs of other measures aimed at reducing the imbalances of the labour market according to the Board of Directors of the Fund.

\section{Extrabudgetary Support of Entrepreneurial Activities}

The method of direct support provided for entrepreneurial activities from the general budget is ineffective and practically unattainable with regard to the overburdened expenditure side of the national budget. Therefore, it is necessary to apply indirect methods of supporting starting businesses in the form of providing tax concessions (Chapter IV), and to find new extrabudgetary sources of finance. Within the framework of the Complex Support Programme for Small- and Medium-Sized Businesses in the Slovak Republic, several specialized institutions have been established for this purpose (the Slovak Guarantee Bank, the National Agency for the Development of Small-and Medium-Sized Enterprises, Consolidation Bank, etc). Some new measures have been adopted in the field of export promotion as well. Through the Society for Export Credit Insurance, the government assumes responsibility for the repayment of export loans to financial institutions on behalf of domestic producers, if the payments for the exported goods (services) are not realized in the customer's country for political reasons. The Society also provides subsidies to cover the losses of enterprises caused by differences between domestic and foreign rates of interest in the case of credited exports of commodities of mechanical engineering and investment nature. An especially significant source of extrabudgetary funds is represented by foreign loans (granted by the 
International Monetary Fund, the World Bank, the European Bank for Reconstruction and Development, the European Investment Bank, the European Union, the G-24 countries, the Exim Bank of Japan, etc.) The fiscal agent in the case of these loans is the Government, the foreign exchange is deposited with the National Bank of Slovakia, while the utilization of the these loans (in Slovak currency) is decided by the Slovak Government with the relevant international institution's consent.

In the field of public investments, extrabudgetary resources obtained from the sale of government bonds represent a significant supplementary source of finance. These resources were used mainly for the financing of housing development projects and the construction of hydro- projects at Gabcikovo, Malinec, Turcek and Selice. The government bonds were marketed in 1992 and 1993 through auction and periodic sales in the amount of 12.0 billion Czechoslovak (Slovak) crowns, while the maturity of these bonds ranged from 1.5 to 5 years.

\section{PROPORTION OF THE STATE BUDGET REVENUE, EXPENDITURE, AND DEFICIT IN THE GROSS DOMESTIC PRODUCT}

The Gross Domestic Product (GDP) of the Slovak Republic is recorded in two forms: GDP in constant prices, and GDP in current prices.

\section{GDP in constant prices}

The generated Gross Domestic Product is converted to a comparable price level (1983). This indicator is used to express the trend of the annual development of GDP. In the period from 1984 to 1994, the GDP in constant prices developed as follows:

\begin{tabular}{|c|c|c|c|c|}
\hline Ye a r: & 1984 & 1985 & 1986 & 1987 \\
\hline \multicolumn{5}{|l|}{ GDP in Sk billions } \\
\hline (constant prices) & 193.1 & 201.0 & 209.2 & 214.6 \\
\hline Annual develop. index & 100.0 & 104.1 & 104.1 & 102.6 \\
\hline Ye ar: & 1988 & 1989 & 1990 & 1991 \\
\hline \multicolumn{5}{|l|}{ GDP in Sk billions } \\
\hline (constant prices) & 218.6 & 220.9 & 215.4 & 184.1 \\
\hline Annual develop. index & 101.9 & 101.1 & 97.5 & 85.5 \\
\hline Ye ar: & 1992 & 1993 & 1994 & \\
\hline \multicolumn{5}{|c|}{ GDP in Sk billions (estimate) } \\
\hline (constant prices) & 179.6 & 173.8 & 180.0 & \\
\hline Annual develop. index & 97.696 .8 & \multicolumn{2}{|c|}{103.6} & \\
\hline
\end{tabular}




\section{GDP in current prices}

The proportion of State budget revenues, expenditures, and deficits in the Gross Domestic Product should be calculated with regard to the development of inflation, i.e. the values of GDP must be recorded in current prices of the relevant year.

$\begin{array}{lrrrr}\text { Y e a r: } & 1984 & 1985 & 1986 & 1987 \\ \begin{array}{l}\text { GDP in Sk billions } \\ \text { (current prices) }\end{array} & 93.1 & 203.3 & 212.7 & 216.9 \\ \begin{array}{l}\text { Annual develop. index } \\ \text { Y e a r : }\end{array} & 100.0 & 105.3 & 104.6 & 102.0 \\ \begin{array}{l}\text { GDP in Sk billions } \\ \text { (current prices) }\end{array} & 1988 & 1989 & 1990 & 1991 \\ \begin{array}{l}\text { Annual develop. index } \\ \text { Y }\end{array} & 103.7 & 104.1 & 104.1 & 115.0 \\ \begin{array}{l}\text { Y e a r : } \\ \text { GDP in Sk billions (estimate) }\end{array} & & & \\ \quad \text { (current prices) } & 301.8 & 340.2 & 396.0 & \\ \text { Annual develop. index } & 107.7 & 112.7 & 116.4 & \end{array}$

The individual components of the State budget in the given period were as follows:

$\begin{array}{lrrrr}\text { Y e a r : } & 1984 & 1985 & 1986 & 1987 \\ \text { Revenues (in Sk billions) } & 82.0 & 85.7 & 87.4 & 89.7 \\ \text { Annual development index } & 100.0 & 104.5 & 102.0 & 102.6 \\ \text { Expenditures (in Sk bn) } & 82.0 & 85.7 & 87.4 & 89.7 \\ \text { Annual development index } & 100.0 & 104.5 & 102.0 & 102.6 \\ \text { Budget deficit (in Sk bn) } & 0 & 0 & 0 & 0 \\ & & & & \\ \text { Y e a r : } & 1988 & 1989 & 1990 & 1991 \\ \text { Revenues (in Sk billions) } & 93.3 & 91.4 & 95.3 & 116.9 \\ \text { Annual development index } & 104.0 & 98.0 & 104.3 & 122.7 \\ \text { Expenditures (in Sk bn) } & 93.3 & 92.8 & 95.8 & 127.1 \\ \text { Annual development index } & 104.0 & 99.5 & 106.4 & 132.7 \\ \text { Budget deficit (in Sk bn) } & 0 & 1.4 & 0.5 & 10.2 \\ & & & & \\ \text { Y e a r : } & 1992 & 1993 & 1994 & \\ \text { Revenues (in Sk billions) } & 115.9 & 150.3 & 139.1 & \\ \text { Annual development index } & 99.1 & 129.7 & 92.5 & \end{array}$




$\begin{array}{lrrr}\text { Expenditures (in Sk bn) } & 123.8 & 173.3 & 162.0 \\ \text { Annual development index } & 97.4 & 140.0 & 93.5 \\ \text { Budget deficit (in Sk bn) } & 7.9 & 23.0 & 22.9\end{array}$

The proportion of the total revenue, expenditure, and deficit of the State budget of the Slovak Republic in the Gross Domestic Product (in current prices) in the period 19841994.

$\begin{array}{lcccr}\text { Y e a r : } & 1984 & 1985 & 1986 & 1987 \\ \text { GDP in Sk bn (current p.) } & 193.1 & 203.3 & 212.7 & 216.9 \\ \text { Revenues (in Sk billions) } & 82.0 & 85.7 & 87.4 & 89.7 \\ \text { Proportion (in \%) } & 42.5 & 42.2 & 41.1 & 41.4 \\ \text { Expenditures (in Sk bn) } & 82.0 & 85.7 & 87.4 & 89.7 \\ \text { Proportion (in \%) } & 42.5 & 42.2 & 41.1 & 41.4 \\ \text { Deficit (in Sk billions) } & 0 & 0 & 0 & 0 \\ \text { Proportion (in \%) } & - & - & - & - \\ & & & & \\ \text { Y e a r : } & 1988 & 1989 & 1990 & 1991 \\ \text { GDP in Sk bn (current p.) } & 225.0 & 234.2 & 243.6 & 280.1 \\ \text { Revenues (in Sk billions) } & 93.3 & 91.4 & 95.3 & 116.9 \\ \text { Proportion (in \%) } & 41.5 & 39.0 & 39.1 & 41.7 \\ \text { Expenditures (in Sk bn) } & 93.3 & 92.8 & 95.8 & 127.1 \\ \text { Proportion (in \%) } & 41.5 & 39.6 & 39.3 & 45.3 \\ \text { Deficit (in Sk billions) } & 0 & 1.4 & 0.5 & 10.2 \\ \text { Proportion (in \%) } & - & 0.6 & 0.2 & 3.6 \\ & & & & \\ \text { Y e a r : } & 1992 & 1993 & 1994 \text { (est.) } & \\ \text { GDP in Sk bn (current p.) } & 301.8 & 340.2 & 396.0 & \\ \text { Revenues (in Sk billions) } & 115.9 & 150.3 & 139.1 & \\ \text { Share (in \%) } & 38.4 & 44.2 & 35.1 & \\ \text { Expenditures (in Sk bn) } & 123.8 & 173.3 & 162.0 & \\ \text { Share (in \%) } & 41.0 & 50.9 & 40.9 & \\ \text { Deficit (in Sk billions) } & 7.9 & 23.0 & 22.9 & \\ \text { Share (in \%) } & 2.6 & 6.8 & 5.8 & \\ & & & & \end{array}$

In the period from 1984 to 1988 , under the conditions of central planning, the State budget was drafted to be a balanced one, excluding the possibility of deficit. The impacts of the radical economic reform started in 1991 resulted in a growing budget deficit.

The above data indicate that 1993 and 1994 were specific years, which influenced the share of budgetary factors in the Gross Domestic Product. The birth of an independent Slovak Republic, the division of federal property, and the introduction of a new tax system caused structural changes in the budget revenues, which affected their 
total volume. On the other hand, the demands on expenditures considerably increased, mainly due to the establishment of new constitutional bodies and central authorities of state administration.

The new system of social security and health care required the establishment of an institution for the financing of health, sickness, and pension funds (National Insurance Corporation). In 1993, the revenues and expenditures of the Corporation went through the State budget. On 1 January 1994, the National Insurance Corporation became independent of the State budget; this resulted in a considerable drop in budget revenues and expenditures.

The performance of the State budget in 1993-1994 was considerably influenced by the system of clearing with the Czech Republic. At 31 December 1993, the clearing account balance of the Slovak Republic recorded a deficit of Sk 5.8 billion. After adjustments, the deficit would increase to Sk 28.8 billion and its share of GDP would reach $8.5 \%$. A different situation occurred in 1994, when the Slovak Republic not only repaid this sum, but reached a surplus on clearing account in the amount of Sk 8.2 billion. After taking the effects of clearing into account, the budget deficit will drop to Sk 8.9 billion and its share of GDP to $2.2 \%$ (estimate).

\section{BUDGET DEFICIT FINANCING}

Although in the past current budget deficits were directly financed by the central bank, since 1992 the Slovak Republic has been striving for transfer to market mechanisms to be implemented through short-term securities (T-bills).

The current budget deficits are caused by time discrepancies between state budget revenue and expenditures. Based on short-term predictions of budget revenue and expenditures development the Ministry of Finance determines a volume and time schedule of particular T-bills to be issued. These are issued in a dematerialized form, i.e. by being booked in a nominal value of 1 million Sk and sold in the form of a discount at auctions. Their yield covers a difference between their nominal value (due date value) and issue value (auction sale value).

The National Bank of Slovakia is a sale agent acting as a short-term securities market custodian at the same time. Participants in this market are bank entities, investment companies and investment funds as well as other juridical persons using this form to evaluate their funds free within a short period of time. The participants in the market might be divided into direct and indirect participants, i.e. those who can make a purchase at the primary market and make a trade at the secondary market directly, and those who can join the market only through an intermediator (that is through a direct participant). The T-bills may be purchased also by the central bank, however, only up to a limit fixed to $5 \%$ of real state budget revenue of a previous year. In the course of the year, the Slovak Republic state budget development has a fairly significant volatility. Due to the unbalanced development there are great differences in a T-bills sold volume and consequently, differences in a trade market volume of the securities. In some cases of failing budget development predictions, or financial market insufficiency to absorb all issued T-bill volumes as the case may be, an exceptional direct loan in the form of the socalled technical debit limited to 5 business days is provided by the central bank. During this period of time, the Ministry of Finance can improve the situation by another issue or 
in any other manner. Upon excess of a 5 day limit, a sanction interest rate amounting to a doubled current discount rate is applied by the National Bank of Slovakia. At present a state budget expenditure account selective blocking system is developed to prevent budgetary deficits from direct loaning.

\section{STRUCTURAL ANALYSIS OF BUDGET EXPENDITURES}

\section{Direct Taxes}

The system of direct taxes is formed by corporate profit tax and personal income tax (earned income - wages, income from entrepreneurial activities, capital income, rental income, and other income).

\section{Corporate Profit Tax}

The subject of corporate profit tax is income earned by legal entities with a seat in the Slovak Republic from any activity, and from the disposal of any property, unless provided otherwise by law. Legal entities whose seat is outside the Slovak Republic are subject to tax on income earned from sources located in the territory of the Slovak Republic. The tax rate has been set at $42 \%$ of the tax base, which is defined by the difference between the total revenue and total expenditure incurred in achieving, procuring, and maintaining the revenue. The following items may be deducted from the tax base: the value of financial and material gifts donated for the support of science, culture, education, fire protection, youth activities, and contributions to social, health, ecological, humanitarian, charitable, religious purposes, and sports, provided the value of the gift is at least Sk 2,000. However, the total amount of deductions may not exceed 2\% of the tax base.

For the stimulation of entrepreneurial activities, the following items have been exempted from corporate income tax: interest on foreign currency deposits, earnings from the operation of small-scale hydroelectric stations, heat pumps, solar collectors, biogas production plants and equipment exploiting geothermal energy, and yields on government bonds. Profits from the manufacture of equipment specially designed for the collection, transport, treatment, and disposal of dangerous waste are also exempt from taxation.

To provide indirect support for small and medium-scale businesses, the Government has approved a regulation according to which corporate taxpayers established after 1992 are exempted from corporate profit tax for a period of one or two years respectively. Another regulation makes it possible for newly established businesses to ask for a 50\% tax respite in the first year, $30 \%$ in the second and third years, and $25 \%$ in the forth and fifth years. If the taxpayer continues in the business for at least 5 years after being granted a tax respite, and if he uses the unpaid tax for the development of his business, he shall be released from the obligation to repay the deferred tax.

\section{Personal Income Tax}

Taxable items include:

a) earned income (wages); 
b) income from entrepreneurial activity;

c) income from capital (dividends/interest);

d) rental income;

e) other income.

Income from dependent income-earning activity (earned income) is defined as income earned by an employee, or a member of an organization, or a statutory body of a legal entity, in the form of wages, salaries, or fees. Earned income also include the salaries of government officials, members of parliament, executives of central government offices, and fees paid to the officials of local governments, bodies of state administration, civil, and friendly associations, professional chambers, and other bodies and institutions.

Income from entrepreneurial activity is a revenue earned from business activity, agricultural production, forestry and water economy, or from another independent income- earning activity, including the publishing of literary and other works at own expenses.

Capital income (interest and dividend incomes) is formed by dividends, yields of securities, interest, and other income from credit, loans, and deposits, as well as discounted bills of exchange.

Rental income is earned from the rental charges of real property, houses or flats, and from the renting of movable property except occasional rental.

Other income includes earnings from occasional business activities, random, or onetime receipts, proceeds from the sale of own real property, income from the occasional renting of movable property, etc.

The tax base (basis of assessment) is the sum by which the specified revenues exceed the expenditures necessary for the achievement of these revenues. The tax base may be reduced annually by Sk 21,000 per taxpayer. Apart from this, the following deductions are permitted: children);

- Sk 9,000 per year for each dependent child living with the family (up to four

- Sk 12,000 per year for wife (husband), living in the same household, if he/she has no own income exceeding Sk 21,000;

- Sk 12,000 per year, if the taxpayer receives disability pension, or Sk 6,000, if the taxpayer receives a partial disability pension.

The tax rate is of a progressive nature, depending on the tax base reduced by deductible items. The minimum rate is $15 \%$, the maximum is $42 \%$.

In general, direct tax revenues represent approximately a 30\% share of the total budget revenue at both republican and local government levels.

\section{Indirect Taxes}

On 1 January 1993, a new tax system was introduced in the Slovak Republic. The 1993 tax reform was prepared according to the federal scenario for economic transformation, and was designed to replace the numerous turnover taxes with a value added tax and a system of excise taxes. In the period from 1993 to 1994, the tax laws 
concerning indirect taxes were partly amended with regard to the new conditions of the independent Slovak Republic. The amendments concerned mainly the tax rates, the basis of assessment, the conditions of tax collection, and the budget revenues from the individual taxes.

\section{Value Added Tax (VAT)}

The following items are taxable under VAT: all taxable activities performed for payment or without payment, including natural transactions in the Slovak Republic, while taxable transactions include supplies of goods, construction and transfer of real estate, provision of services, assignment or utilization of rights to industrial or intellectual property, and the import of goods. Taxable persons in the Slovak Republic are all persons whose business activities result in taxable transactions; in the case of commodity imports, the taxpayers are persons to whom the imported goods are delivered. In the case of occasional coach transport services rendered by a foreign company in the Slovak Republic, the tax is to be paid by the foreign company.

The tax base is represented by the purchase price of the commodity less VAT, or in case of selling a commodity or real property by auction, the auction price less VAT. The basic VAT rate on commodities is $25 \%$ (except goods specified by law, which are taxable at a rate of $6 \%$ ). The basic rate of VAT on services is $6 \%$ (except services specified by law, which are subject to $25 \%$ VAT).

A taxpayer is entitled to tax deductions, in case he uses the purchased goods, buildings, real estate, services, or rights for his business activities under conditions stipulated by law. However, he has no right to apply tax deductions if he cannot prove his right by tax vouchers, or if he has bought a car, goods, or services for the purpose of entertainment or as a gift.

Tax exemption is provided for the following items: postal services, radio and television broadcasting, financial services, insurance services, transfer or leasing of land and buildings, training and education, health services and sanitary equipment, social security services, lottery and other games of chance, the delivery of returnable containers, the sale of a company, and non-profit-making activities.

Imported goods are subject to taxation; in this case, the tax base is the sum of customs duty, excise tax, and the base for the calculation of customs duty. Export of goods, international transport, provision of services and the assignment of rights abroad are exempt of taxation.

\section{Excise Tax on Wine}

The excise tax on wine is applicable to wine, champaign, or cider made in the Slovak Republic, or imported into the Slovak Republic. The tax is payable by the legal entity or private individual who produces, imports, or exports wine. The tax base is the taxable volume of wine expressed in litres. The tax rate is Sk 5.00 per litre (wine), Sk 23.30 per litre (champaign), and Sk 16.30 per litre (desert wine).

\section{Excise Tax on Beer}

The excise tax on beer is applicable to beer brewed in the Slovak Republic, or imported into the Slovak Republic. Imported beer is subject to taxation, even in case it is exempt from customs duty. The excise duty is payable by the legal entity of the private individual who produces, imports, or exports beer. The tax base is defined by the taxable 
amount of beer expressed in litres. The tax rate is Sk 1.54 per litre (beer up to 10.6\%); Sk 3.40 per litre (of beer from 10.7 to $13.6 \%$ ); and Sk 4.23 per litre (beer above $13.7 \%$ ).

\section{Excise Tax on Spirits}

The tax is applicable to spirits and alcohol produced in the Slovak Republic, or imported into the Slovak Republic. The taxpayer is the legal entity or private individual who produces, imports, or exports spirits or alcohol. The tax base is given by the volume of spirits expressed in litres of pure alcohol (100\% etylalcohol). The tax rate is Sk 210 per litre of $100 \%$ alcohol.

\section{Excise Tax on Tobacco and Tobacco Products}

The tax is applicable to tobacco and tobacco products produced in the Slovak Republic, or imported into the Slovak Republic. The taxpayer is the legal entity or private individual who produces, imports, or exports tobacco or tobacco products. The tax base is given by the amount of tobacco expressed in kilograms, or the number of tobacco products in pieces. The tax rate is Sk 0.30 , or Sk 0.58 per piece (cigarettes); Sk 0.0 per piece (cigars); and Sk 35.00 per kg (tobacco).

\section{Excise Tax on Hydrocarbon Fuels and Lubricants}

The tax is applicable to hydrocarbon fuels and lubricants produced in the Slovak Republic, or imported into the Slovak Republic. The taxpayer is the legal entity or the private individual who produces, imports, or exports hydrocarbon fuels and lubricants. The tax base is the volume of fuel and lubricant expressed in tons of net weight. This does not apply to compressed gass used as fuel, here the tax base is the volume of gas expressed in cubic metres. The tax rates are Sk 9.390 per ton (motor gasoline and kerosine with a lead content above $0.013 \mathrm{~g} /$ litre); Sk 8.250 (Diesel oil); Sk 2.370 per tons (gas used as fuel); and Sk 2.0 per cubic metre (compresses gas, used as fuel).

Indirect tax revenues form the most significant component in the revenue side of the budget, representing almost $50 \%$ of the total budget revenues.

\section{Other Taxes}

\section{Land Tax}

The land tax is applicable to gardens, arable land, vine- yards, orchards, fish-ponds, forest lands, build-up areas, land, building sites and other lands. The taxpayer is the owner, or permanent user of the real estate. The tax base is the price of land determined by multiplying the actual area of the land with the price of land per 1 square metre according to the effective tariffs, or the total area of taxable land in square metres. The tax rate is differentiated, it ranges from $0.25 \%$ to $1.0 \%$ of the tax base. Land owned by the state or local governments is exempt from taxation.

\section{Tax on Buildings}

The tax is applicable to residential houses, weekend cottages, garages, building for entrepreneurial activities, and other structure, except for dams, water mains, sewerage systems, heat energy distribution, and public roads. The tax is paid by the owner or tenant of the building concerned. The tax base is given by the total built-up area in square metres. The tax rate is differentiated according to purpose of the building: from Sk 1.9 to Sk 10.0. Buildings owned by the state, local communities, or foundations are exempt from tax. 


\section{Inheritance Tax}

The inheritance tax is applicable to inherited movable and immovable property, domestic and foreign currencies, securities and receivables, or other rights to property. The taxpayer is the heir/heiress who has inherited the property, or its part, according to the legally valid inheritance proceedings. The tax base is the value of the inherited property after deducting the debts and liabilities of the testator, related to this property, and the adequate costs of the testator's funeral. The tax rate is differentiated according to the tax base and the relationship between the heir/heiress and the testator.

\section{Gift Tax}

The gift tax is applicable to movable or immovable property, receivables, securities, and other proprietary rights acquired as a gift. The tax is payable by the acquisitor of the donated property, while the donor quarantees the payment of tax. The tax base is the money value of the acquired property in the place and at the time of donating after deducting the documented debts and the partial payment. The tax rate is differentiated according to the tax base and the family or other relationship between the donor and the person who has accepted the gift.

\section{Tax on the Transfer of Real Estate}

The tax is applicable to the transfer of ownership of real estate against payment. The taxpayer is the seller; the buyer guarantees the payment of tax. The basis of assessment is the payment for the real estate, based on the agreed price, however, not less than the price determined according to special regulations. The tax rate is differentiated, depending on the tax base and the family relation to the seller.

\section{Road Tax}

The road tax is applicable to motor vehicles, used for entrepreneurial activities, or in connection with a business activity. The tax is payable by the legal entity or private individual who is registered as owner of the motor vehicle. In the case of utility vehicles and buses, the basis of assessment is the total weight of the vehicle in tons and the number of axles, in the case of personal motor cars, their stroke in cubic centimetres. The tax rate is differentiated according to a special tariff. Vehicles used in health and social services, vehicles used by fire brigades, rescue teams, diplomatic missions, embassies and consulates, vehicles of public transport, and vehicles specified by law are exempt from taxation.

The revenues from other taxes are negligible compared with revenues from direct and indirect taxes; they represent less that $1 \%$ of the total budget revenue.

\section{Nontax Revenues}

\section{Customs Duties}

Customs duties are levies imposed by the government on goods that cross the customs border of the country, and form a part of the state budget revenues. Import duties are payable on any imported commodity with the exception of goods specified in the customs tariffs as customs-free goods. Export duties are imposed on exported commodities, only if specified in the customs tariff. Besides import and export duties, the 
government may impose antidumping duties (on imported goods which are subject to antidumping duties, countervailing duties (imposed to countervail a subsidy or premium which was provided for the production or export of goods), or retaliatory duties (additional fees to tax rates, or special customs duties imposed on goods, which are not subject to taxation according to the customs tariff), while the retaliatory duties may be fixed for a temporary period, because of economic retaliation for goods imported from a country, which discriminates against the Slovak Republic in the field economic relations. The customs tariff contains a commodity nomenclature, general and contractual customs rates, as well as preferential tariff rates following from international agreements and unilateral measures.

The State intends to introduce a system of active support for commodity imports having the character of property deposits (new progressive technologies) in line with the priorities of macroeconomic and regional development in the field of environmental protection. To create customs-free zones with the aim of obtaining progressive technologies and know-how necessary for the development of ecologically clean methods of production.

Customs duties represent approximately 3 to $4 \%$ of the total annual revenue of the State budget of the Slovak Republic.

\section{Transfers from NBS Profits and Interest on State Assets}

In accordance with the National Bank of Slovakia Act, the Central Bank of the Slovak Republic (NBS) manages its finances according to a budget approved by the Bank Board. The Bank covers its inevitable operating costs from its own revenues. The Bank uses the profit it generates to replenish the level of its reserves and other funds created from profits, and for other purposes in accordance with the budget. The Bank transfers its remaining/unallocated profit to the State budget of the Slovak Republic. At present, this disbursement to the State budget represents approximately $75 \%$ of the profits generated by the Central Bank (NBS). For credit balances on the accounts of the State budget and financial assets of the State, the National Bank of Slovakia pays interest to the State in the amount of the actual discount rate. As a result of these two entitlements, the Central Bank has a share of 5 to $6 \%$ in the state budget revenues.

\section{Other Revenues}

Other revenues represent approximately $8 \%$ of the total budget revenue. Their main part comes from the repayments of government loans extended in the past, i.e. mainly the repayments of selected investment projects and loans extended to foreign entities in a social field. Other sources of funds are the earnings of budgetary organizations and the transfers of subsidized companies, administrative fees, penalties, and other minor receipts.

The total proportion of nontaxable revenues in the state budget revenues of the Slovak Republic is roughly $20 \%$.

\section{Income from Privatization}

Income from privatization does not form a source of revenues for the State budget, and is directed to an institution specially established for this purpose - the National Property Fund of the Slovak Republic. 


\section{EXPENDITURES STRUCTURAL ANALYSIS}

\section{Subsidies upon Purchase of Goods and Services}

The Slovak Republic fiscal policy is aiming at gradual reduction of subsidies to goods and service prices. By 1989, subsidies and interventions of prices amounted to more than $14 \%$ of total state budget expenditures. They referred to a wide range of products and services (for instance, sugar, wood, water, milk, eggs, meat, heat energy, transport costs, etc.). At present subsidies to public transport and heat energy for citizens, and those covering a difference between a purchasing price and final consumer price of some dietetic products are provided by the state budget. In 1994 the volume of these subsidies amounted to 5.6 billion Sk which is approximately $4 \%$ of the total state budget expenditures. Subsidies to public transport are to cover losses caused by passenger railway and bus transport, and drop in transport company earnings providing tariff reductions of transport charges to selected population groups. An amount of the reductions (especially workers and students reductions) is gradually reevaluated for the purpose of diminishing an impact on state budget. The 1994 volume of public transport subsidies amounted to 3.2 billion Sk out of which a railway passenger transport percentage amounted to 2.1 billion Sk and a bus urban and suburban transport (excluding public transport paid by community budget) share to 1.1 billion Sk. In the central planning system, prices of heat energy supplied to citizens were fixed directively and resulted in substantial deformation. At present these prices are still regulated and subsidized by the state budget, however, they have raised almost seven times compared to 1989. At the moment, subsidies to heat prices amount to more than 2 billion $\mathrm{Sk}$ covering a difference between a regulated heat price paid by citizens and a higher selling price. Interventions of agricultural product prices are not provided directly from the state budget but through the State Agricultural Market Regulation Fund and the State Land Management and Food Support Fund.

\section{Enterpreneur Sector Subsidies}

In 1994 enterpreneur sector non-investment subsidies amounted to 7.6 billion Sk (5.5\% of the total budget expenditures). A major part of this amount (6.8 billion Sk) was provided to an agrocomplex having supported especially agricultural transformation, restructuring and modernization under new market conditions. These subsidies are considered to support extraproduction agriculture functions by gradually reducing support of production functions. The measures adopted aim is state food safety, healthy nourishment and nutrition sufficiency of population, economic stability, appropriate revenue and well-balanced agricultural development in regions. Forestry was subsidized by 0.3 billion $\mathrm{Sk}$ and it having been used for cultivation costs and work of overall social benefit. The cultivation subsidies are mainly oriented towards forest cultivation, elimination of drought and fire consequences and implementation of genofund protection and maintenance programme. As far as the work of overall social benefit is concerned, the main points were elimination of damage caused by biotic vermin overpopulation, afforestation and reforestation and forestry ecosystem revitalization spraying. Water management was subsidized by 0.2 billion $\mathrm{Sk}$ aiming at territorial protection against 
water harmful effects, river and brook administration, navigation conditions support and performance of other public useful activities. Subsidies amounting to 0.3 billion Sk were allocated to mining, metallurgy and energy industries due to decline of ore mining and elimination of mining consequences in order to support coal mining in relation to brown coal mining conception, to solve several consequences of stopped production in Niklová huta Sereš and to store 4 items of fuel cells for Russia based on a signed contract related to A-1 Jaslovské Bohunice Nuclear Power Plant disposal. Enterpreneurs were given also investment subsidies amounting to 2.1 billion Sk (1.5\% of total budget expenditures), predominantly for railway modernization and reconstruction including combined transport development. These subsidies were also provided focused on water tanks completion and other investment activities of public benefit in competence of water and sewage enterprises as well as water management construction. The subsidies were also used to solve urgent problems of hazardous waste in the form of priority implementation of regional incinerator projects in compliance with an approved waste management conception. Apart from the above subsidies in the 1994 state budget, the amount of 1.6 billion Sk was allocated to economic stabilization, structural programmes and weapon industry conversion.

\section{Classic State Services}

This expenditures group includes budgetary funds provided to state social consumption. They incorporate defence and security, jurisdiction and public prosecutors offices, science and technology, administration and other public state consumption expenditures. Defence expenditures amounting to 8.8 billion Sk (6.3\% of the budget expenditures) cover inevitable material requirements (food, kit, fuel, lubricants) as well as repairs, maintenance and services necessary for military operation and activities. At the moment funds provided to items which are not directly related to the Slovak Republic Army activities, such as elimination of excessive technological equipment pursuant to European Security and Cooperation Conference conclusions, rebuilding of air force to the ICAO system, special stock costs, financing of the UNPROFOR peace corps and elimination of ecological consequences after departure of the former Soviet Army. Due to investment expenditures buildings under construction connected with reorganization and redislocation alterations are to be completed and new buildings are to be constructed (for example, army, air force and ecological constructions and a social programme).

Security expenditures include those required by the Ministry of the Interior Security Division, the Prison and Justice Guard Corps, the Slovak Intelligence Service, railway police and railway army corps. For the above purposes, the amount of 5.6 billion Sk (4\% of the budgetary expenditures) was allocated in 1994. Ministry of the Interior Security Division expenditures also include funds provided to solve migration policy and to support security corps sports representation. The amount of 0.6 billion $\mathrm{Sk}(0.4 \%$ of the budgetary expenditures) was provided to jurisdiction and public prosecutors offices. This amount covers Slovak Republic Constitutional Court of Justice, Ministry of Justice courts and Public Prosecutors' Offices inevitable operational requirements. This also takes into account alterations in remuneration of judges and law school graduates engaged in judicial practice as well as public prosecutors and law school graduates engaged in legal practice. In the field of science and technology, the amount of 1.7 billion Sk (1.2\% of the budgetary expenditures) is allocated to operation and activities 
performed by research and development budgetary and subsidized agencies. At the same time funding covers 78 science and technology tasks having been elaborated in the previous years and continued to be pursued including state defence and security tasks. Administration expenditures amount to 4.5 billion Sk (3.2\% of the budget expenditures) out of which 2.5 billion Sk are allocated to salaries. Other material expenditures ensure inevitable operation of ministries and other state administration central bodies, the Slovak Republic President Office, the Slovak Republic National Council Office and the Supreme Audit Office. They also cover budget expenditures unavoidable to operation of state budgetary agencies established within competence of ministries and state administration central bodies. It concerns expenditures of the Central Customs Administration and its organization elements, the Central Tax Directorate, tax offices and financial audit offices, statistical administration offices, district and borough councils, environmental offices, forestry offices, regional agricultural and information centres and foreign service. Other state public consumption expenditures incorporate miscellaneous ministry expenditures amounting to 20.6 billion Sk (14.9\% of the budget expenditures). They cover, for instance, road administration and maintenance expenditures, state funds subsidies, expenditures required by state tangible reserves, a fire department, civil defence etc. Besides the above also expenditures of obligatory insurance provided by the National Insurance Company, employers insurance companies and contribution made to the Employment Insurance Fund for state budgetary and subsidized agencies belong there.

\section{Public Social and Cultural Services}

This item includes funds allocated to social services provided and activities performed to citizens (the so-called public consumption). It concerns mainly expenditures of public consumption basic industries, it means school and heath systems, culture (excluding state administration expenditures in these industries), church and civic association contributions and others. The Slovak Republic school system requires approximately $11.7 \%$ of the total budget expenditures (16.2 billion Sk). The funds promote creating of conditions necessary for basic school operation considering priority tasks to be accomplished in education process and state youth care. A part of the funds is provided to foreign students and to cover costs of secondary apprentice schools within other ministries. Sports (except sports representation) are funded through the State Physical Culture Fund. State budget health system expenditures amount to about 2 billion Sk ( $1.5 \%$ of total budget revenue). They cover expenditures of hygienic services, secondary nursing schools, prevention and treatment, costs of activities resulting from hygiene and epidemiology competence transfer and from tasks to be accomplished by state antidrug policy. They also refer to funding of activities resulting from the Slovak Republic having joined the AIDS and CINDI international projects and from monitoring health conditions of population living in polluted areas, etc. Other health care expenditures go through the Health Insurance Fund. The state budget finances cultural expenditures amounting to 2.1 billion Sk ( $1.5 \%$ of the budget revenue). These funds are allocated to budgetary and subsidized agencies (such as libraries, theatres, ensembles, museums, galleries, specialized technical-methodological cultural institutions, and exhibitions) as well as to particular tasks to be performed. Allocations of funds to cultural monument restoration, children`s books, national minority press and activities, church and catholic charity funds as well as national minority cultural association contributions 
are calculated in this package. The state budget also contributes to running of the Slovak Radio, the Slovak Television and the Slovak Republic Press Agency. An additional financial source of cultural needs is the State Culture Fund of Pro Slovakia. The other public consumption expenditures cover hospital care, nursing services, guardian care, judicial and extrajudicial rehabilitation compensation, young couple loan state contributions and environmental protection expenditures.

\section{Pension Security and Other Social Programmes}

Pensions, and sickness and health insurance benefits are financed through the National Insurance Company (see Chapter 1/6). Old-age and invalidity pensions, pensions paid to certain citizens after reaching a determined age, widows`and widowers` benefits and other pensions and benefits are paid within a pension insurance scheme. The sickness insurance includes sickness benefits, benefits provided to a person taking care of a family member, maternity allowances, pregnancy contributions and benefits to insured persons. Expenditures to both active and passive employment policies are paid from the employment insurance fund. From the state budget, expenditures directed to social security are as follows:

- non-system social security benefits (10.6 billion $\mathrm{Sk}$ ),

- state insurance paid to the Pension Insurance Fund for a specific group of citizens (5.3 billion $\mathrm{Sk})$,

- state insurance paid to the Pension Insurance Fund in order to increase pensions as the only source of income, to provide valorization of pensions, to raise war veteran pensions, and insurance paid in case of rehabilitation and to limp persons incapable to move (2.2 billion Sk),

- state insurance paid to the Sickness Insurance Fund for a selected group of citizens ( 0.1 billion $\mathrm{Sk})$,

- social care benefits (3.6 billion Sk), and

- sickness insurance benefits and pensions, and non-system social security benefits based on chapters of the Ministry of Defence, Ministry of the Interior, the Ministry of Justice and the Slovak Intelligence Service (1.1 billion Sk). The non-system social security benefits are those provided by the state even under terms and conditions of the National Insurance Company performing its duties and which will be a part of a social security new conception to be implemented within a social reform. They include pension insurance expenditures, it means social pensions, increase of pensions paid to limp persons incapable to move, spouse pensions, benefits paid to pensioners raising children, and other benefits and contributions. Apart from that, the non-system sickness insurance benefits include children's allowances, a contribution upon child`s birth, funeral contribution, spa social security and state social benefits (parent contributions, contributions paid to a person taking care of another one, contributions for using an appartment, compensation of wages and salaries of soldiers doing their military service, etc.).

State contributions to both the Pension Insurance Fund and Sickness Insurance Fund for a selected group of persons (except for paying an insurance charge for state budgetary and subsidized agencies employees) are sources of pensions and sickness 
insurance benefit expenditures. Payment of the social benefits is mainly oriented to socially dependent families with children, the physically handicapped and persons requiring special care. The sickness insurance benefits and pensions, and non-system social security benefits are provided to the Ministry of Defence, Ministry of the Interior, Ministry of Justice and Slovak Intelligence Service also by the state budget considering that employees of these industries performing their duties of civil servants do not benefit from National Insurance Company social care. The need of funds to pay the social security benefits takes into account an increased life minimum ceiling, and address and purpose of the benefits are pursued in compliance with social budgetary policy orientation. Completing a system of providing addressed benefits and its coming into practice will help to solve social needs of population groups which are really dependent on these funds. The state budget social expenditures total of 22.9 billion Sk amounts to $16.5 \%$ of the total budget expenditures.

\section{Public Investment}

The 1994 Slovak Republic state budget financed public investment amounting to 9.3 billion Sk ( $6.7 \%$ of the total budget expenditures). This package is based on budgetary policy objectives assuming reduced public sector construction and state administration organization structure rationalization and respecting priority accomplishment of new tasks resulting from an independent state establishment. There is a different approach to particular industries in structural orientation of public investment expenditures. The major criterion is to set priorities to buildings being constructed and in some cases, to accomplish tasks related to new terms of reference after the federation split. They concern especially military facilities, intelligence service, establishment of embassies and consulates, location of diplomatic corps, building up border crossings, etc.

The amount of 2.1 billion Sk out of the total of 9.3 billion Sk is oriented towards a health system. The funds are to cover needs of hospitals and surgical facilities under construction, hygiene and epidemiology institutions being built up, modernization of diagnostic and therapeutic technologies, and purchase of new high-tech medical equipment. In the school system the amount of 1.0 billion Sk covers mainly completion of schools, sports halls and canteens under construction as well as inevitable purchase of machinery and equipment. Investment expenditures of other industries totally amounting to 3.7 billion Sk are mainly aiming at completion of buildings under construction, and new investment is considered only in exceptional cases. Housing policy expenditures are another particular issue which is one of the most important and socially most sensitive parts of state economic and social policies. In connection to an ongoing economic reform process the complex housing issue to be solved requires major changes to be made in a housing development system which has been implemented up to now. Inspite of substantially limited sources, funds amounting to 2.5 billion Sk have been allocated from the state budget to develop housing policy in the form of both direct state support (subsidies) and, especially, indirect support. It concerns a housing savings state premium to be provided which can annually amount up to $40 \%$ of a saved amount, however, not exceeding 6000,- Sk. At the same time there is a possibility to get a loan with an advantageous interest rate. Another part of state budget finance is to cover an Investment and Development Bank property loss resulting from a difference of interest rates of advantageous loans provided in the past to solve citizens` housing issues. Requirements 
related to construction, repairs and maintenance of highways and state roads are financially covered by Road Management State Fund finance.

\section{Debt Service}

The debt service main objective is to pay off effectively direct state liabilities totally amounting to 23.4 billion Sk (16.9\% of the total budgetary expenditures). Out of this amount, foreign liabilities amount to 11.5 billion $\mathrm{Sk}$, in compliance with concluded agreements and assumed installments. They include mainly government loan expenditures in both special and civil areas, expenditures of gas activities performed in Russia, loan installments paid by the Ukraine Dolinská extraction complex, loan installments of a central foreign exchange source and interest rates of approved government loans. Internal liabilities amounting to 11.9 billion Sk are based on budgetary results from 1991 to 1994 and on disbursed yield of state bonds issued pursuant to valid acts. They include the state bonds issued to cover housing under construction in 1992, a state budget deficit in 1991 and 1993, completion of the Gabcikovo water works, and Malinec and Turcek water reservoirs, completion of housing in 1993 and damages recognized to be paid to citizens. Out of the total of 23.4 billion Sk, the expenditures resulting from Slovak Republic commitments made by the former federation amount to almost $69 \%$ (16.1 billion Sk). A state bond yield amounts to $5 \%$ (1.2 billion $\mathrm{Sk}$ ) and the rest of $26 \%$ (6.1 billion Sk) refers to state budgetary liabilities (direct loan and T-bills interest rates as well as bank fees charged for keeping accounts and bank services).

\section{NATIONAL DEBT}

The level of the national debt and its structure was to a considerable extent affected by the division of the former CSFR on 1 January 1993. At this date, the national debt of the Slovak Republic amounted to Sk 22.1 billion and consisted of the following parts:

- credit extended by the central bank to cover the 1991 budget deficit: Sk 7.4 billion

- credit extended by the central bank to cover the 1992 budget deficit: Sk 3.4 billion

- Government Treasury bills issued to cover the 1992 budget deficit: Sk 4.5 billion

- Government bonds: Sk 6.8 billion

In accordance with the law concerning the division of federal property between the two successor states and the relevant interstate agreements, the Slovak Republic took over its share of the federal budget deficit in the amount of one-third, i.e. Sk 2.3 billion, and one-third of the liabilities to the former State Bank of Czechoslovakia resulting from government loans ( $\mathrm{Sk} 13.0$ billion), and one- third of the liabilities resulting from the devaluation and revaluation of the Czechoslovak currency ( $\mathrm{Sk} 8.7$ billion). Thus, the internal debt of the Slovak Republic vis-a-vis the banking system increased to Sk 46.1 billion.

Under the succession of government loans from the former CSFR, the Slovak Republic inherited liabilities worth Sk 10.9 million, liabilities and claims/receivables incorporated in the Central Foreign Exchange Resources (Sk 20.1 billion), and a part of the loans granted by the International Monetary Fund (Sk 13.5 billion). The inherited 
foreign debt amounted to $\mathrm{Sk} 44.5$ billion; this means that the total debt of the Slovak Republic was Sk 90.6 billion at 1 January 1993.

In the course of 1993 and 1994, the internal and foreign debts of the Slovak Republic increased. The internal debt was unfavourably influenced by the 1993 budget deficit (Sk 23.0 billion), which had to be covered by an issue and sale of government bonds according to a decision of Parliament. By the end of 1994, only Sk 8.0 billion worth of bonds were placed on the capital market, the remaining Sk 15 billion was covered by a direct credit extended by the central bank. Apart from bond issues to cover the budget deficit, the Government issued bonds to finance housing development projects, the construction of the hydroelectric scheme at Gabcikovo and the water reservoirs at Malinec, Turcek, and Selice. The total volume of government bonds reached Sk 16.9 billion by the end of 1994. The 1994 budget deficit is fully covered by government Treasury bills, which are purchased mainly by commercial banks and partly by nonbank entities.

A survey of the total debt of the Slovak Republic (in Sk billions)

\begin{tabular}{|c|c|c|c|c|}
\hline Internal debt & 1 Jan. & & $31 \mathrm{Dec}$. & Differ- \\
\hline 19 & & 1994 & ence & \\
\hline 1991 Deficit - credit & 7.4 & & 7.4 & 0 \\
\hline 1992 Deficit - credit & 3.4 & & 0 & -3.4 \\
\hline 1992 Deficit - T/bills & 4.5 & & 0 & 4.5 \\
\hline 1992 Deficit - inherited from CS & R 2.3 & & 2.3 & 0 \\
\hline 1993 Deficit - credit & 0 & & 15.0 & +15.0 \\
\hline Liabilities from govern. loans & 13.0 & & 13.0 & 0 \\
\hline Liabilities from devalu- & & & & \\
\hline ation and revaluation & 8.7 & & 8.7 & 0 \\
\hline T-bills for 1994 deficit & 0 & & 22.9 & +22.9 \\
\hline Government bonds & 6.8 & & 16.9 & +10.1 \\
\hline Internal debt - total: & 46.1 & & 86.2 & +40.1 \\
\hline External debt & $\begin{array}{l}1 \text { Jan. } \\
1993\end{array}$ & & $\begin{array}{l}31 \mathrm{Dec} . \\
1994\end{array}$ & $\begin{array}{l}\text { Differ- } \\
\text { ence }\end{array}$ \\
\hline Central Forex Resources & 20.1 & & 18.8 & -1.3 \\
\hline Government loans & 10.9 & & 16.4 & +5.5 \\
\hline IMF loans & & 19.7 & +6.2 & \\
\hline Foreign debt - total: & 44.5 & & 54.9 & +10.4 \\
\hline Total national debt & 90.6 & & 141.1 & +50.5 \\
\hline
\end{tabular}

The above figures clearly show that the internal debt significantly contributed to the growth in the total debt of the Slovak Republic in 1993 and 1994, mainly as a result of the State budget deficit, and the financing of the issue of government bonds. The internal debt in the given period increased by $87 \%$, while foreign debt grew by $23 \%$, and Slovakia's total indebtedness by $56 \%$. 
According to preliminary data, the share of the internal debt in the Gross Domestic Product reached $21.8 \%$ by the end of 1994 ; that of the foreign debt $13.9 \%$; and that of the total debt $35.7 \%$.

The per capita internal debt of the Slovak Republic was roughly Sk 16.900; the per capita foreign debt amounted to Sk 10,700; and the total debt reached Sk 27,699 (approx. USD 900) per capita by the end of 1994.

These amounts do not include plus items, i.e. state financial assets, the surplus money of state funds, the balances of the accounts of local authorities, and the clearing liabilities of the Czech Republic, which improve the net position of the Slovak Republic to a certain extent.

\section{ECONOMIC DEVELOPMENT}

\section{Tendencies of Economic Development in 1993}

The division of the Czecho - Slovak Federal Republic, the associated division of the Czecho-Slovak currency, extensive tax reform, and the recession in neighbouring Western European economies, influenced the development of the Slovak economy in 1993.

The origin of an independent state and independent economy on 1.1.1993 caused an interruption to the continuity of economic relations and processes, and so initiated an adaptational phase of the economic development of the new state.

A decline in the performance of the economy already appeared in the first quarter of 1993, and only moderated in the course of the year. The development of industrial production documents the changes in the economic situation. The decline of industrial production in individual quarters, in comparison with the same period of the preceding year, constantly varied around a level of $10 \%$. This decline was to a large extent caused by a reduction in external demand, and only partly by restriction of domestic demand. After the change of the domestic supply relations with the Czech Republic into foreign trade relations, Slovak industry became sensitive to developments in the economies of neighbouring states and Germany. The decline of industrial production only partly led to a decline in employment. In most areas it led to a decline in the productivity of work, which fell by an average of $8 \%$ over the whole of industry.

The most negative development in labour productivity occurred in branches where the most significant rise in prices accompanied a fall in production (food production and oil refining).

In the structural development of industry, the tendency to strengthen production of things which are demanding in terms of energy and material, but require a low level of processing continued. This appeared in the different degrees of decline in production between the extractive - energy industries (-8.4\%) and processing industries $(-18.6 \%)$, in the low decline of the chemical and smelting industries, and the higher decline in the engineering and other finished product industries. There was a significant decline in oil refining. Marketing opportunities made the position of companies of the processing industries difficult, so a great part was lost or incapable of payment. 
The question of the conversion of weapons production, and increasing the competitiveness of products with a higher level of processing, remains a long-term unsolved problem.

The establishment of private companies and subsidiaries of foreign companies, and the identification of unsuccessful companies must be solved in the systematic area.

In 1993, the proportion of small and medium sized companies in productive industry changed by over $18 \%$.

There was an unfavourable development in construction. The decrease of investment demand in the business and budget spheres caused a decline of a quarter in the output of the construction industry. After division of the federal state, the market area for construction diminished. At the same time, the export of construction capacities declined. The surplus construction capacities of large companies did not find complete application.

The transformation of construction was a positive phenomenon. In the structure of production, more than $50 \%$ fell to private and non-state companies. They showed a growth in production by more than $23 \%$. In 1993, the proportion of small and medium sized companies active in the construction industry, increased to $50 \%$.

In 1993, agriculture succeeded in reversing the process of divergence in price between inputs and outputs at the expense of the consumers of food. The decline in gross agricultural production is estimated at around 7\%. A more significant growth of prices for agricultural products compared to the previous year, at a level of $14.6 \%$, partly improved the economic situation of agricultural enterprises.

The privatization of state enterprises in agriculture, should be carried out in the second wave of coupon privatization.

The service sector developed more favourably than the primary and secondary sectors. In creation of gross domestic product, production of market services reached a share of about $36 \%$, and non market services about $11 \%$.

The private sector, including cooperatives for agricultural production, took a share of about two fifths in industrial production, one fifth in construction, half in goods transport, and $85 \%$ of market trade.

In 1993, compared to the previous year, the demand of the population (expenditure for private consumption at constant prices), and the demand for investment, decreased. The market changes caused by the transformation process changed the branch structure of investment. The extent of investment in finance and insurance and the area of commerce and other services changed. The investment opportunities in agriculture were reduced by the limitation of subsidies from the state budget, and the change in the structure of demand by the population, resulting from liberalization of prices. There was a revival of investment in telecommunications, but generally a significant limitation of investment in the sector of public services. In manufacturing industry, investment in the area of producing intermediate products stabilized. In general investment activity in the first three quarters of 1993 , private companies were responsible for $7.1 \%$, cooperatives for $4.1 \%$, communal enterprises for $6.6 \%$, state enterprises for $70.2 \%$, enterprises in foreign and international ownership for $6.2 \%$, and other mixed enterprises for $5.8 \%$. 
Costs were influenced by the changing level of labour costs, changes in the productivity of workers, and as a result of external imbalances, which led to a $10 \%$ devaluation of the Slovak crown. The total cost of labour had a rising tendency with systematic growth in nominal wages (average monthly wages in industry grew by $24 \%$ compared to 1992). The combination of a growth in total labour costs, with a decline in the productivity of labour caused a significant growth in total labour costs per one unit of production, by 26\% compared to 1992 .

The development of prices reacted to the disturbance of the internal balance. Out of the total growth of prices in 1993, a significant part occurred at the beginning of the year, as a result of tax reforms. Restraint of the growth of prices of industrial products and the prices of building work, compared to the growth of consumer prices, was caused by state regulation of the prices of energy, fuels and transport tariffs, the greater sensitivity of consumer prices to growth in wages, and the inadequate development of the competitive environment in the retail sector. Restraint of the prices of agricultural products, compared to the growth of other prices, resulted from the relations between supply and demand in the area of agricultural products.

The continuing economic decline and worsened access to foreign labour markets, influenced the situation on the labour market. At the end of 1993, in comparison with 1992, the number of workers in industry was $11 \%$ lower, in construction $16 \%$, but in commerce it was higher by $22 \%$. The number of workers employed in the private sector grew by $49 \%$ in industry in the same period, but fell by $11 \%$ in construction. At the end of the year, the rate of unemployment reached $14.4 \%$.

The development of the balance of payments was uneven, and with a relatively large proportion of material and financial relations between the Czech Republic and Slovakia, it was dependent on the development of the balance of payments with the Czech Republic. The deficit of the commercial balance, worsened the initial positive result in the balance of the current account. By the end of the year, a devaluation of the Sk in relation to the clearing ECU by $5 \%$ occurred, and at the same time a revaluation by $3 \%$ of the Czech crown against the ECU. The growth in the deficit of the clearing account towards the Czech Republic led to a continuation of the agreed marginal credit, and payment of this difference.

The relatively low level of gross debts in convertible currencies, taken over on the division of the foreign debts of the federal state, as also the favourable debt servicing, favourably influenced the debt position of the SR in 1993. In the total debts of the SR, of 2.9 billion USD, the government has a share of $39 \%$, the NBS $31 \%$, and the banking sector $30 \%$.

The creation of an independent monetary system in the SR, after the division of the Czech and Slovak currencies in February 1993, also required the creation of an independent monetary policy. The basic aims corresponded to the requirements of continuing the process of transformation of the Slovak economy, and were defined as stabilization of the national currency, suppression of inflationary tendencies, maintenance of a balanced balance of payments, and strengthening the currency reserves in convertible currencies.

The monetary programme with the values of monetary statistics, inflation $17 \%$, the raising of net credit of the government at 15.8 billion Sk, growth of M2 by $12 \%$, decline 
of production by $4 \%$ and an unchanged rate of money in circulation, determined monetary policy at the beginning of 1993. After the first half year, in relation to the real development of the economy, the monetary programme for the second half of 1993 was determined on the basis of these assumptions: raising of net credit of the government by 22 billion Sk, inflation 25\% to 30.4\% (including devaluation of the currency and import surcharge) and a decline in production by $5.2 \%$. A monetary review, including the development of credit, the development of the budget economy, the foreign position of the SR, and the development of deposits (aggregate M2), was used to monitor monetary development. The NBS used direct and indirect instruments to achieve the aims of monetary policy. The indirect instruments included application of credit limits. Refinancing resources in the form of auction refinancing credit, lombard loan and bill of exchange trade had a special place among the indirect instruments. In the course of 1993, the structure of refinancing was changed in favour of auction refinancing credit, with a simultaneous change in the level and form of interest of the bill of exchange trade and lombard loan.

In carrying out its own monetary policy, the central bank of the SR was influenced by factors such as the division of the federal state, the origin of an independent currency, the introduction of a new tax system, liberalization of prices, change in the exchange rate of the Slovak currency, and the specific economic development of the independent state.

\section{Tendency of Economic Development in 1994}

After three quarters of the year, economic growth was $4.3 \%$ growth in GDP at constant prices. By last September, GDP at constant prices reached 137.1 billion Sk, and in current prices 294.9 billion Sk. Growth in industrial production from the side of aggregate supply, which grew by $6.1 \%$ compared to the same period of 1993 , and increased exports in the area of aggregate demand, had the greatest share in this development.

Private consumption grew by $1.2 \%$ and reached a volume of 65.4 billion Sk at constant prices. Public consumption declined by $4.2 \%$ and reached 35.2 billion Sk. Gross formation of capital fell by $12.5 \%$. At the same time pure exports grew and reached 15.4 billion Sk at constant prices.

In the area of industry, goods worth 291.4 billion Sk were produced. This was $6.1 \%$ more than in the first three quarters of 1993. Production of 153.4 billion Sk was created in the private sector. Its share in industrial production reached $52.6 \%$. The productivity of the work of the average industrial worker increased by $8.4 \%$ and reached $497,524 \mathrm{Sk}$. The average monthly salary reached $6,221 \mathrm{Sk}$, which meant a growth of $18.7 \%$ compared to the previous year.

In the construction industry, production worth 29.7 billion Sk was achieved. This represented a decline of $8.1 \%$ compared to the level of the same period of 1993 . The productivity of the average construction worker exceeded the level of the first three quarters of 1993 by $1.4 \%$, and reached 199,902 Sk. The average monthly salary exceeded the previous level by $16.6 \%$, and reached $6,149 \mathrm{Sk}$. The productivity of labour, compared to the comparable period grew by $2.8 \%$.

The retail trade grew steadily, and after three quarters of the year achieved $15.1 \%$ growth, and a value of 166.3 billion Sk. The process of privatization of commercial 
activity was reflected in retail sales, which fell by $28.3 \%$ in the public sector, and increased by $25.5 \%$ in the private sector. The private sector had a total share of sales of $88 \%$.

Unfavourable weather conditions, resulting in a fall in animal products, influenced the development in agriculture.

The prices of industrial products increased by $15.7 \%$ from the beginning of 1994 . In terms of areas of industry, the prices of products of the chemical and rubber industries increased by $38.7 \%$, of the printing industry by $17.7 \%$, of the clothes industry by $17.6 \%$, and the food industry by $17.3 \%$. Prices in the energy industry fell by $3.3 \%$. Up to the end of September 1994, the prices of industrial products were $17.9 \%$ higher that at the same time in 1993. The price of construction work increased by $11.1 \%$. The price of agricultural products grew by $9 \%$, including a rise in the cost of vegetable products by $2.7 \%$, and of animal products by $14.2 \%$.

Three quarters of the way through 1994, employment was $0.5 \%$ lower, compared to the same period of 1993. The average recorded number of workers was 1,955,100 people. The greatest declines in employment were in construction with $12.8 \%$ fewer workers, extraction of mineral raw materials with $12.1 \%$ fewer, and education with $5.5 \%$ fewer.

At the end of September, the level of unemployment was $14.3 \%$. The number of free working places grew. Three quarters of the way through 1994, there were 28 unemployed people to each vacant job, compared to 37 in 1993.

Investment, amounting to 64.3 billion $\mathrm{Sk}$, was carried out in the first 9 months of 1994. This was $0.9 \%$ less than in the same period of 1993. The greater part of the investment $(64.4 \%)$ was financed from the investors' own resources, with $12.7 \%$ financed by credit, $10.4 \%$ by grants from the state budget, and $5 \%$ of the total amount invested coming from foreign resources. Compared to the same period of 1993, the intensity of investment in the public sector fell by $13.1 \%$, while it increased by $28.3 \%$ in the private sector.

By the end of September 1994, 32,327 private companies registered in the commercial register, existed in Slovakia. From the total recorded number of 33,905 organizations, private companies formed 95.3\%. 280,255 private businessmen and 258,776 self employed people were registered in the SR.

Companies in private ownership took a $72.9 \%$ share in construction work, a $52.6 \%$ share in industrial production, and an $88 \%$ in retail turnover. Private transport provided $17.7 \%$ of the total volume of transport. Private companies employed $58.6 \%$ of industrial workers, $78.2 \%$ of construction workers, $60.2 \%$ of workers in commerce, and $10.9 \%$ of transport workers. The private sector created $46.2 \%$ of GDP.

After three quarters of 1994, foreign capital invested in the Slovak economy reached a level of 13.7 billion Sk. The participation of foreign capital was recorded in 6,703 organizations. 2,464 organizations with a total capital of 4.3 billion Sk were registered with exclusively foreign capital. Registered international organizations with domestic and foreign capital participation numbered 4,240.

The largest amount of foreign capital went into the processing industries ( 6.8 billion $\mathrm{Sk}$ ), commercial and repair activities (3.5 billion $\mathrm{Sk}$ ), and to finance and insurance (1.8 billion Sk). Germany, Austria, the Czech Republic and the USA participated in the total amount of foreign capital in the SR. 
In carrying out its monetary programme for 1994, the National Bank of Slovakia achieved the basic aim of stabilizing the currency. In the monetary programme for 1994, the NBS set the aim of keeping the inflation rate at 10 to $13.2 \%$. In the first 11 months of 1994, the annual inflation rate reached $10.9 \%$. The monetary restriction, which the NBS applied in the first quarter of 1994, succeeded in significantly reducing the rate of inflation. The average annual rate of inflation from the beginning of the year to the end of September was $13.8 \%$, as a result of which the real interest rate on deposits with a time limit of a year became positive. In 1994, the nominal average interest rate on short-term deposits was already higher than the average annual rate of inflation from the beginning of the year. The real interest rates on credits moved into the position of positive rates.

The ending of the dollarization tendency in the Slovak economy was an important result of the stabilization of the currency in 1994. This fact was manifested in the increased creation of crown deposit accounts in the banking system of the SR. The growth was greatest in the case of short-term crown deposit accounts.

By internally stabilizing the currency, the NBS succeeded in stabilizing the Slovak currency externally as well. The growth of foreign currency reserves, as a result of the positive development of the balance of payments, had a decisive effect on strengthening the position of the Slovak crown. In 1994, the NBS maintained the exchange rate of the Slovak crown at the same level. In 1994, the liberalization of the approach of the commercial banks to the foreign currency fixing of the NBS, was an important measure. This secured a more flexible management of the foreign currency position of the commercial banks. In the course of the year, the NBS introduced a change of the currency basket of the Slovak crown, from a five member, to a two member basket of currencies. This step considered the actual ratio of currencies in the balance of foreign payments of the SR. In the new basket, the German mark represents $60 \%$ of the value, and the American dollar $40 \%$.

The NBS's strategy for entering the international capital markets included the successful issuing of NBS bonds, strengthening its rating ambitions and increasing its foreign currency reserves. In the middle of 1994, the Japanese agency, the Japan Bond Research Institute, granted the SR a rating evaluation of BBB for the level of investment rank.

The NBS achieved the aim set for the creation of foreign currency reserves in 1995 , by September 1994. The total foreign currency reserves of the banking system including gold, reached almost 3.4 billion USD. During the first 11 months of 1994, foreign loans shared in strengthening the foreign currency reserves of the NBS by an amount of 460 million USD, which represented 37\%. In the course of 1994, the NBS issued 151 foreign currency licenses for the acceptance of credits from convertible currency foreigners. The amount of credit drawn from abroad represented the equivalent of 14.2 billion Sk.

A positive turn in the development of the current account balance of payments occurred in the first quarter of the year, as a result of a growth of the surplus in the balance of services. In September 1994, a positive turn in foreign trade also occurred. The positive balance of the trade balance reached 666 million Sk, that is 20.6 million USD.

By the end of September 1994, the gross indebtedness of the SR reached 4.1 billion USD. Out of this, the indebtedness of the Slovak government was 2.3 billion USD. 
Calculated as an amount for one inhabitant of the SR, the total gross foreign currency debt was 774 USD at the end of September 1994.

\section{AIMS FOR THE FUTURE}

The main aim for the immediate future is to prepare the foundations for long-term, sustainable economic growth, and achievement of the sort of long-term economic parameters, which will allow the economy of the SR to take a place in the European Union. It will be necessary to restructure the economy, continue the privatization process, orient the economy towards exports, and consolidate the budgetary situation.

Clear definition of the responsibilities of the institutions of the state administration, and coordination of economic policy will be required. In the framework of transformation, it will be necessary to complete the programme of restructuring and privatization of the banking system, and development of the capital market. The process requires development of the public sector, education and the health service. Development of the privatization process will require application of variants and variable methods of privatization, with support for the entry of foreign capital to the privatization process.

The need to prepare the conditions for more perfect adaptation of the business sector to market conditions will be unavoidable. On the financial market, it will be necessary to moderate the dominant position of some financial institutions, improve the legislative conditions, and increase the pressure of financial institutions on the business sector.

The future requires limitation of monopoly tendencies, equalization of legal conditions for the business sector and activities, improvement of the access of companies to credit resources, and further financial resources to stimulate business activities. Development of the capital market, must include transparency, effectiveness and effective controls.

Stabilization of the macro-economic environment will require consolidation of budgetary policy and the creation of conditions for a stable exchange rate for the Sk. Future price stability will depend on ending the decline in employment, and on prudent development of pay.

Future development will require the implementation of a financial policy, which will be an active element in securing prosperity and restructuring policies with the simultaneous restraint of short-term and long-term risks for the area of monetary policy and debt servicing of the state.

A pro-growth economic environment will also be created by measures leading to strengthening the foreign currency reserves of the economy, and by the implementation of a pro-export policy to overcome the protectionist, information, organizational, advisory and propagational barriers and inadequacies in penetrating developed competitive markets. 


\section{REFERENCES}

(These are all in Slovak)

* NBS Act, No.566/1992

* Banking Act, No.21/1992

* Act No.600/1992 on Securities

* Act No.530/1992 on Bonds

* Act No.191/1950 on Bills of Exchange

* Act No.248/1992 on Investment Companies and Investment Trusts

* Organizational Structure of the National Bank of Slovakia, Bratislava 1993

* Annual Report 1993, National Bank of Slovakia, Bratislava 1994

* Monetary Survey, NBS, July 1993 - October 1994

* Economic Development of the SR in 1993, EØ SAV, Bratislava

* Development of International Trade in the SR, HN, October 1994

* Basic Macro-Economic Proportions of the development of the Economy of the SR in 1994, PØ SAV, Bratislava 1994

* Economic Reform in the SR, HN, September 1994

* Problems of the Economic Transformation of the SR, HN, December 1994

* The Position of Slovakia in the Transformation Process I-V, HN, December 1994

* Report on the Development of the Capital Market in the SR, HN, April 1994

* The Economic Base of the Central European Countries - a favourable factor for the development of the capital market, HN, October 1994

* The Slovak Economy from Recession to Revival, HN, July 1994

* Foreign capital in Slovakia, HN, October 1994

* Characteristic Features of the Beginning of Transformation, HP, June 1993 


\section{Table of Contents}

INTRODUCTION 3

1. The Transformation Process 3

2. The Transformation of Property Rights 4

3. Liberalization of Prices 4

4. Liberalization of Foreign Trade 4

5. Reform of the Tax System 5

6. Social Security 5

7. The Social Programme 6

8. Development of Financial Institutions 6

9. Privatization of the Business Sector 9

I. CLASSIFICATION AND PREPARATION OF THE STATE BUDGET 11

1. A Brief History of the National Budget of the Slovak Republic 11

2. Structure of the 1994 State Budget 16

3. Structure of Local Budgets for $1994 \quad 17$

4. Extrabudgetary Funds 18

5. State Financial Assets and Liabilities 20

6. Social, Sickness, Health, and Unemployment Insurance 20

7. Extrabudgetary Support of Entrepreneurial Activities 21

II. PROPORTION OF THE STATE BUDGET REVENUE, EXPENDITURE, AND DEFICIT

IN THE GROSS DOMESTIC PRODUCT $\quad 22$

III. BUDGET DEFICIT FINANCING 25

IV. STRUCTURAL ANALYSIS OF BUDGET EXPENDITURES 26

1. Direct Taxes 26

2. Indirect Taxes 27

3. Other Taxes 29

4. Nontax Revenues 30

5. Income from Privatization $\quad 31$

V. EXPENDITURES STRUCTURAL ANALYSIS $\quad 32$

1. Subsidies upon Purchase of Goods and Services $\quad 32$

2. Enterpreneur Sector Subsidies $\quad 32$

3. Classic State Services 33

4. Public Social and Cultural Services 34

5. Pension Security and Other Social Programmes 35

6. Public Investment 36

7. Debt Service 37

$\begin{array}{ll}\text { VI. NATIONAL DEBT } & 37\end{array}$

VII. ECONOMIC DEVELOPMENT

1. Tendencies of Economic Development in $1993 \quad 39$

2. Tendency of Economic Development in $1994 \quad 42$

VIII. AIMS FOR THE FUTURE $\quad 45$

REFERENCES $\quad 46$

Table of Contents $\quad 47$ 